\title{
Lines of Action for Sexting Prevention and Intervention: A Systematic Review
}

\author{
Mónica Ojeda ${ }^{1}\left[\right.$ Rosario Del Rey ${ }^{2}$
}

Received: 2 August 2019 / Revised: 23 June 2021 / Accepted: 23 June 2021 / Published online: 17 November 2021

(C) The Author(s) 2021

\begin{abstract}
Sexting has become a new form of intimate interaction in line with contemporary communication methods. This phenomenon often leads to positive outcomes, but it can also have negative repercussions depending on the situation, such as the context of the relationship, and whether it is consensual or coercive. Despite this, the main types of sexting behaviors (sending, receiving, and third-party forwarding) must be addressed in order to promote safe and healthy practices. However, the approach to tackling this phenomenon remains unclear. This systematic review sought to summarize the lines of action proposed or conducted in the scientific literature to address sexting, to help researchers and educators create and evaluate effective programs. A systematic search of 21 databases was conducted; only articles relating to sexting education, prevention, and intervention among child and adolescent populations were considered. In total, 456 articles were identified, 91 of which were included for the purposes of this research. The results highlighted a need to respond to the aforementioned sexting behaviors and to tackle the resulting conflict situations. Although interventions across different areas are recommended (e.g., health, family, policies, legal advice, law enforcement, technology experts, and even society as a whole), most studies agree that school is the most practical setting for intervention. Thus, the 15 lines of action identified in this systematic review must all be considered to effectively address sexting in childhood and adolescence.
\end{abstract}

Keywords Sexting $\cdot$ Childhood $\cdot$ Adolescence $\cdot$ Lines of action $\cdot$ Systematic review

\section{Introduction}

Social networks and digital media have become a major part of our daily lives, exerting an increasingly significant impact on individuals in general and, more specifically, on adolescents (Smith et al., 2016). Digitally driven communication fosters positive interactions and has multiple benefits, but it can also bring about new challenges (Englander \& McCoy, 2017). The emergence of online communication has been linked to the global rise in messages with sexual content (Sweeny \& Slack, 2017). Today, adolescents can explore their sexuality in new ways, redefining and normalizing more

Mónica Ojeda

monicaojeda@us.es

1 Department of Educational and Developmental Psychology, Faculty of Education Sciences, Universidad de Sevilla, C/ Camilo José Cela, s/n, 41018 Sevilla, Spain

2 Department of Educational and Developmental Psychology, Faculty of Education Sciences, Universidad de Sevilla, C/ Pirotecnia, 19, 41013 Sevilla, Spain recent types of intimate relationships such as sexting - the sharing of self-produced sexual material through electronic means (Barrense-Dias et al., 2017; Schubert, 2014).

Concerns about this phenomenon have grown, and it has attracted considerable attention from researchers, families, teachers, schools, and the media (Anastassiou, 2017; Gewirtz-Meydan et al., 2018; Van Ouytsel et al., 2015). This has occurred as a consequence of its potential negative impact and the effects it can have on adolescent well-being, where sexual content is disseminated without consent or where teens feel peer or partner pressure to engage in sexting behaviors (Klettke et al., 2014; Olivari \& Confalonieri, 2017; Schubert, 2014). Even teachers agree that sexting could cause classroom disruption (O'Bannon \& Thomas, 2014).

The sexting phenomenon may play an influential role in the process of building new relationships as well as in the development of adolescents' sexual behaviors (Ringrose et al., 2012). Therefore, identifying the institutions that need to get involved and the types of actions that need to be taken is key to ensuring effective prevention and intervention in these areas. Thus, this systematic review analyzes the scientific 
evidence that helps identify the lines of action to address sexting.

\section{Definition and Prevalence of Sexting}

There is a lack of general consensus around the definition of sexting. Definitions vary depending on the type of behavior included, alluding to active sexting (such as sending or third-party forwarding) and passive sexting (receiving a message directly from the creator or via an intermediary). They also vary according to the content of the messages (sexual pictures, videos, or text) and the degree of sexual explicitness (suggestive or explicit) (Barrense-Dias et al., 2017). Therefore, the most restrictive definitions exclusively refer to sending sexually explicit pictures (Choi et al., 2016; Marume et al., 2018), whereas the most comprehensive definitions also cover other types of behavior, for example, content dissemination (Mitchell et al., 2012; Villacampa, 2017). In this context, sexting encompasses the sending, receiving, and forwarding of suggestive and explicit sexual pictures, videos, or text messages via cell phones, the Internet, or other electronic means (Mitchell et al., 2012). Because sexting is an evolving concept that has become increasingly complicated (Van Ouytsel et al., 2018), each study and the sexting behavior must be analyzed, as the action to be taken may vary depending on the behavior displayed.

The estimated number of adolescents engaging in sexting is consistently definition dependent (Barrense-Dias et al., 2017). In a recent meta-analysis (Madigan et al., 2018), the average prevalence of sending sexual content was $14.8 \%$; receiving sexts was $27.4 \%$; forwarding a sext without consent was $12.0 \%$; and receiving a forwarded sext was $8.4 \%$. In recent years, sexting rates among youth have seen a rise with increasing age, and no significant gender differences in the rate of sending or receiving sexts have been observed (Madigan et al., 2018).

\section{The Need to Address Sexting}

The practice of sexting is characterized by its psychological, social, and behavioral consequences (Klettke et al., 2014), which can lead to ethical and socio-moral conflicts alongside other concerns about the privacy and protection of personal content (Schubert, 2014).

Results of a recent meta-analysis suggest that the exchange of sexual messages, photographs, and videos through technological devices is associated with sexual behavior (sexual activity, multiple sexual partners, lack of contraception use, etc.) and mental health issues (delinquent behavior, anxiety/ depression, alcoholism, drug consumption, smoking, etc.), especially in younger adolescents (Mori et al., 2019). The consequences of sexting may affect the physical and psychological health of those involved, and adolescents may end up experiencing peer pressure and emotional difficulties (Olivari \& Confalonieri, 2017; Van Ouytsel et al., 2015). However, most studies indicate that these relationships are cross-sectional, and the fact that sexting presents as a problematic behavior would seem to depend on the situation, such as the context of the relationship, and whether it is consensual or coercive (Temple et al., 2019).

Although the bulk of the research focuses solely on consented parties (sending and/or receiving this type of content), the most detrimental action, and therefore the most important when trying to understand the consequences behind this phenomenon, would be the forwarding of sexual content by third parties (Livingstone \& Görzig, 2014; Strassberg et al., 2017). A possible explanation is that sexual content can be spread quickly without consent, reaching undesired recipients, thus increasing its audience and affecting the victim's reputation (Van Ouytsel et al., 2014a, 2014b). Consequently, most efforts should be directed in this area to prevent and effectively intervene in sexting behaviors. As a result of this dissemination, sexting is also associated with other potential risks which can aggravate its possible consequences, such as blackmail, extortion, bullying, and cyberbullying (Döring, 2014; Kopecký, 2015; Medrano et al., 2018; Montiel et al., 2016; Strassberg et al., 2013; West et al., 2014; Woodward et al., 2017).

The gender dynamics that arise from this phenomenon are also noteworthy. Differences in the roles of sexting are observed, and the different practices do not seem to affect boys and girls in the same way. Boys are perceived as those who ask for photographs, whereas girls are seen as those responsible for setting the boundaries (Symons et al., 2018). Moreover, girls usually experience a damaged reputation and tend to suffer the consequences of sexting more than their male peers, the latter even experiencing positive effects which can boost their popularity (Cooper et al., 2016; Dobson \& Ringrose, 2016; Symons et al., 2018; Wood et al., 2015).

In all cases, a robust response to any sexting-related behavior (sending, receiving, and third-party forwarding) is highly recommended. It is clear that the non-consensual forwarding of content to third parties is a type of behavior that must be avoided, and prevention strategies must be taught (Van Ouytsel, et al., 2014a, 2014b). However, young people also need to know how to act when this type of content is received (Mitchell et al., 2012); how to send sexual content safely, if this is indeed the intention; and how to fend off any attempts at peer pressure (Wurtele \& Miller-Perrin, 2014).

Thus, this phenomenon is seen as a challenge for educational institutions and teaching professionals (McEachern et al., 2012), given that incidents brought about by sexting can have a negative impact at school (Van Ouytsel et al., 2014a, 2014b, 2015). Although prevalence is higher outside of school walls, sexting also occurs during school hours (Schubert, 2014). What is more, sexting outside of this 
environment may also have an impact within the school context (McEachern et al., 2012). Because this phenomenon has the power to influence the interpersonal relationship building process, not to mention adolescent sexual development in general (Ringrose et al., 2012), the classroom is an ideal environment for educating individuals on how best to use Information and Communications Technology (ICT) and, more specifically, prevent any negative consequences of sexting (Mura et al., 2014; Theodore, 2011). Educating young people about sexting in schools has the potential to reach far more adolescents, as many young people do not learn about sexuality or this new reality at home. Furthermore, teaching professionals can train and inform parents, fostering positive relationships and building a strong school community that guarantees the continuity of education received by students in both key settings: home and school (Van Ouytsel et al., 2014b). Specifically, teaching professionals can play a crucial role when it comes to addressing this phenomenon proactively and when taking specific preventive actions to address the consequences of sexting (Bhat, 2018; Kopecký, 2012).

\section{Research Question}

Despite the importance of preventing the potential negative consequences of sexting (Van Ouytsel, et al., 2014a, 2014b), information on how to do this effectively remains scarce. As such, there is an obvious need to develop strategies based on scientific research findings (Livingstone \& Smith, 2014), identifying areas and lines of action that can help researchers and educators create and evaluate programs to successfully address sexting. In an effort to bridge this gap, this study aims to systematically describe the available scientific evidence outlining the effective lines of action to tackle sexting. To this end, the present review is guided by the following question: What are the types and frequencies of proposed lines of action for sexting?

\section{Method}

\section{Inclusion and Exclusion Criteria}

This systematic review includes all articles published up until 2018 that meet a predetermined set of inclusion and exclusion criteria.

The specific criteria to determine suitable studies for inclusion in the review were:

a Studies with a target or participant population of children or adolescents aged up to 19 years.

b. Studies that consider sexting as their phenomenon of interest. c. Studies that include information about sexting education, prevention, and/or intervention.

The specific criteria to determine studies that should be excluded from the review were:

a. Studies with an adult target or participant population.

b. Studies whereby the topic of interest is a sexual phenomenon other than sexting, such as grooming, sexual abuse, or pornography.

c. Duplicate articles.

d. Articles with insufficient information because the full text is not available.

\section{Search Strategy}

The search strategy used for this systematic literature review was based on the PRISMA statement (Urrútia \& Bonfill, 2010). The studies were collected from the following 21 databases: Scopus, Web of Science, Dialnet, CSIC, Periodicals Archive Online, SportDiscus, Psicodoc, ERIC, PsycINFO, Sociological Abstracts, PsycArticles, PubMed, Social Service Abstracts, PILOTS, Redalyc, PubPsych, Teacher Reference Center, Science Direct, Elsevier, ACM Digital Library, and IEEE Xplore.

The key words used were sexting, child, minor, adolescent, teen, youth, student, prevention, education, and intervention. The following search query was entered for the title, abstract, and key words: "Sexting AND (child* OR minor OR adolesc* OR teen* OR youth* OR student*) AND (prevention OR education OR intervention)." Before selecting this strategy, other attempts were made, such as "sexting AND adolesc* AND (prevention OR intervention)." The results were examined to find the right balance between sensitivity and specificity. Database searches were conducted up to September 2018.

\section{Data Coding and Analysis}

Article coding was carried out in two phases using an analysis sheet. During the first phase - the abstract screening phasea check was run to ensure that the article abstracts met the inclusion criteria and not the exclusion criteria. To do so, the following data were collected: database, year of publication, authorship, journal/publication, article title, inclusion criteria (a) and (b), and exclusion criteria (a), (b), and (c).

The second phase-full-text eligibility-was carried out on articles that only met the previous inclusion criteria. Checks were run to verify that they also met inclusion criterion (c) and that they did not meet exclusion criterion (d). In this case, the whole publication was analyzed: type of study, area of study (journal/editorial field of study), language, country (country of the participating sample or, if not, the 
first author's home institution), objective(s), methodology, recipients, sample, definition of sexting, instrument, instrument characteristics, evidence of action, type of action, evaluation of action, area of action, and results. Only those articles clearly stating their own definition of sexting were taken into account. Review articles describing the definitions adopted in other articles without taking a personal stance were not considered. In the case of review articles, only recommendations pertaining to the article were considered, and proposals collected from the analyzed articles were discarded.

Coding was undertaken by the principal investigator. Subsequently, $57.2 \%$ of the articles were selected at random and codified equally and independently by a second assessor, easily exceeding the $20 \%$ recommended minimum (GarcíaMoya et al., 2018). During this phase, the sexting definitions found in the articles under study were also categorized, leading to the following category system: specific behaviors by definition (distribution/exchange; sending; sending and receiving; sending, receiving, and forwarding), the type of content (text message; pictures; text messages or pictures; pictures or videos; text messages, pictures or videos; not specified), and the degree of sexual explicitness (explicit; suggestive or explicit; not specified).

The reliability level was high. The percentage of agreement in the abstract screening phase was $91.3 \%$, reaching $92.1 \%$ in the full-text eligibility phase. Disagreements were discussed and resolved in a consensual manner. The articles selected were downloaded using the Mendeley 1.19.3 software program.

Figure 1 shows a summary of the selection process. A total of 456 articles were identified for the systematic review. The abstract was taken into account across all reviews, and 308 articles were excluded as they met exclusion criteria (a), (b), or (c). The full text of the remaining articles was analyzed, and 57 articles were excluded as they did not meet inclusion criteria (c) or they met exclusion criteria (d). Therefore, 91 articles were included in this systematic review. An overview of the general characteristics corresponding to these studies is provided in Appendix.

Once the included articles had been determined, the areas and lines of action found in each article were categorized. The category system resulting from categorizing the areas of action is shown in Table 1. Similarly, the category system resulting from categorizing the lines of action is shown in Table 2.

The sum of the areas, lines of action, and relevant information found in the articles were also categorized by an external reviewer. The reliability level was high (percentage of agreement at $84.2 \%$ ). Disagreements were discussed and resolved in a consensual manner.

\section{Results}

\section{Overview of the General Characteristics of the Studies}

The general characteristics analyzed in the articles were: year of publication, geographical area of origin, subject area, definition of sexting, type of action recommended, and area of action where intervention is deemed necessary.

Regarding year of publication, the reviewed articles were published between 2009 and 2018, as no articles pre-2009 were found on any of the 21 databases. Notably, an increase in publications was observed in 2014; however, wide frequency variability is found and a clear pattern cannot be determined.

In terms of geographical area of origin, $52.2 \%$ of studies were conducted in North America, 27.8\% in Europe, 10\% in Oceania, 4.4\% across several continents, $3.3 \%$ in South America, $1.1 \%$ in Africa, and $1.1 \%$ in Asia.

Regarding subject area, $39.6 \%$ of studies were conducted in the field of health, $26.4 \%$ in psychology, $20.9 \%$ in other social science disciplines, $11 \%$ in education, $8.8 \%$ in sociology and political sciences, $4.4 \%$ in the field of communication, and $3.3 \%$ in the discipline of law.

The definition of sexting varies depending on the specific behavior at play, the type of content, and the degree of sexual explicitness. In terms of the different behaviors, $39.2 \%$ of articles only refer to sending, $23 \%$ generally define sexting as a sharing or exchange process, $17.6 \%$ refer to sending and receiving, and $16.2 \%$ identify the three behavior types: sending, receiving, and forwarding. The type of content behind these messages also varies. Specifically, $29.7 \%$ of articles mention text messages, pictures, and videos; $29.7 \%$ refer only to pictures; $28.4 \%$ refer to text or picture messages; $6.8 \%$ refer to sexual content in general but do not specify the content; $2.2 \%$ refer to pictures or videos; and $2.2 \%$ refer only to text messages. Lastly, $48.7 \%$ include suggestive and explicit content; $43.2 \%$ include only explicit content; and $8.1 \%$ do not specify the type of sexual content behind the definition used (Table 3).

In terms of the type of action recommended, $7.7 \%$ of articles recommend taking actions to address and prevent the potential consequences of sexting, but do not include any interventions or suggest any strategies to make this happen; $85.7 \%$ of articles do propose specific strategies that can be effective when addressing this phenomenon, but do not include any interventions; and 6.6\% present specific interventions to tackle sexting.

Regarding the area of action where intervention is required, $86.8 \%$ of articles indicate that intervention should be school-led. Next, $20.9 \%$ state that the family should intervene, whereas the same percentage of articles (20.9\%) report that family intervention must also involve the school. 


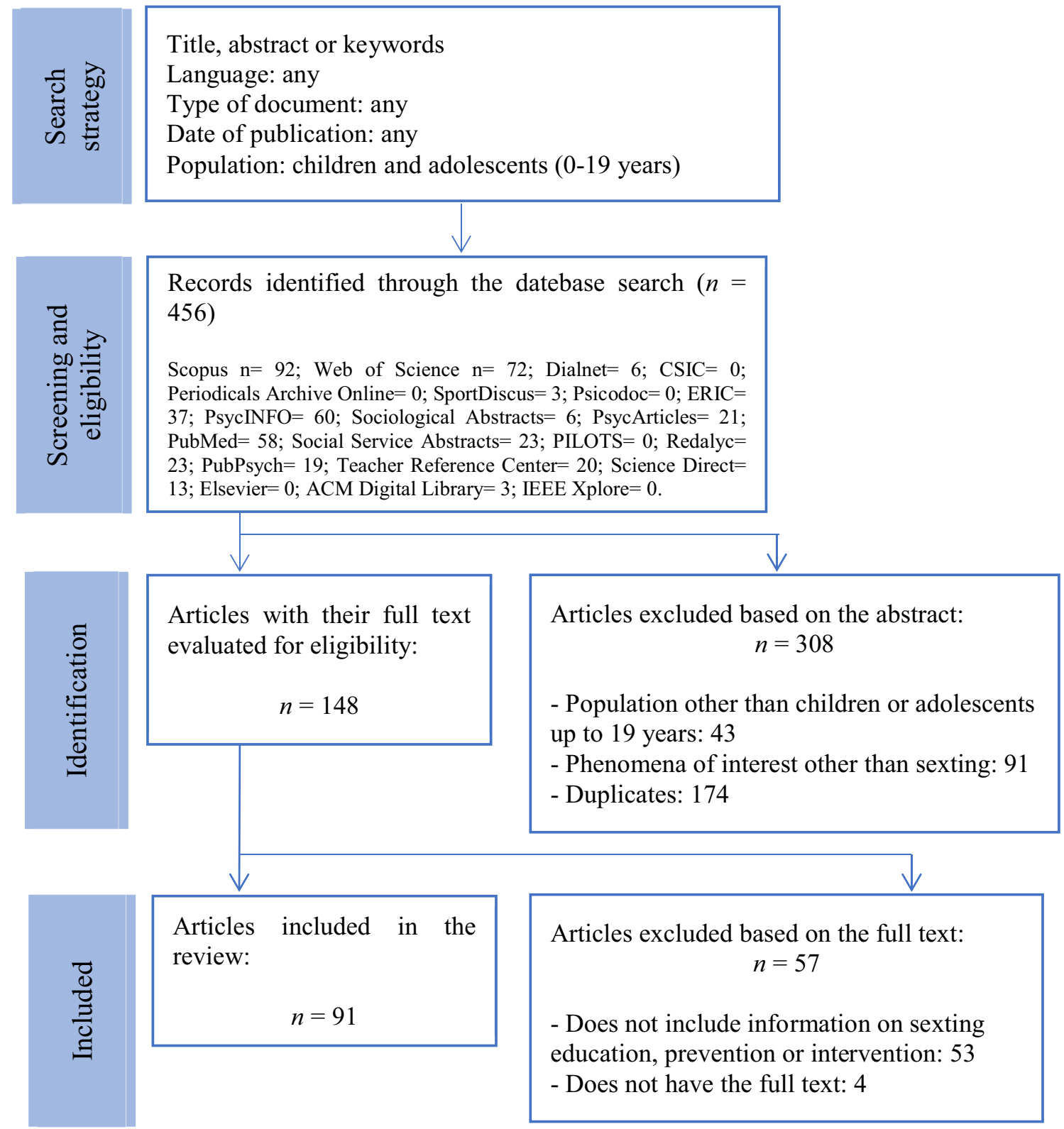

Fig. 1 Review of the article selection process

Similarly, $19.8 \%$ state that action should be taken from a healthcare perspective; $13.2 \%$ from a political perspective; and $7.7 \%$ from across all areas in general. A total of $5.5 \%$ of articles state that family-led involvement should be health based, whereas the same percentage (5.5\%) report how legal advice is required to lend a legal perspective on this phenomenon. Moreover, $4.4 \%$ of articles call for the participation of law enforcement agencies, and $2.2 \%$ note that collaboration from technology experts is also necessary (Table 1).

\section{What are the Types and Frequencies of Proposed Lines of Action for Sexting?}

The collected data have been divided into three different types of information: lines of action, initiatives developed, and main recommendations.

Fifteen lines of action emerged after categorizing the strategies identified in the research papers as key aspects of tackling sexting (Table 2):

A total of $48.8 \%$ of articles recommend developing specific sexting programs; $46.4 \%$ encourage a safe and healthy 
Table 1 Areas of action

\begin{tabular}{|c|c|c|c|}
\hline & Description & $\mathrm{N}$ & $\%$ \\
\hline 1. School & School counselors, educational psychologists, school nurses, teachers, and centers of education in general & 79 & 86.8 \\
\hline 2. Family & Fathers, mothers, guardians & 19 & 20.9 \\
\hline 3. Family through school & $\begin{array}{l}\text { The family's involvement through the school. This refers to situations in which families are encouraged to } \\
\text { engage in school-led actions. The goal is that families take action, too }\end{array}$ & 19 & 20.9 \\
\hline 4. Health & Pediatricians, doctors, nurses, gynecologists, and psychologists & 18 & 19.8 \\
\hline 5. Policies & Politicians, legislators & 12 & 13.2 \\
\hline 6. All areas & In general, or referring to the community or society as a whole & 7 & 7.7 \\
\hline 7. Family through health & $\begin{array}{l}\text { The family's involvement through the health sector. This refers to cases in which health professionals } \\
\text { engage the family. The goal is that families take action, too }\end{array}$ & 5 & 5.5 \\
\hline 8. Legal advice & Specialists in the legal sector (legal advisers, legal point of view) & 5 & 5.5 \\
\hline 9. Law enforcement & Law enforcement authorities & 4 & 4.4 \\
\hline 10. Technology experts & Web designers & 2 & 2.2 \\
\hline
\end{tabular}

use of ICT, the Internet, and social media; $34.5 \%$ recommend raising awareness about the consequences and risks associated with sexting; and $31 \%$ set out the need to incorporate sexting into sex education programs. Furthermore, $28.6 \%$ recommend training professionals; $23.8 \%$ recommend promoting sexual ethics; $20.2 \%$ highlight the need to raise awareness about gender roles and stereotypes; and 19\% advocate developing rules and implementing protocols. A total of $17.9 \%$ of articles encourage coherence among the different parties involved; $15.5 \%$ set forth the need to work on risk factors associated with peer groups; $15.5 \%$ call for the ideas and experiences of adolescents to be heard and used; and $11.9 \%$ recommend improving the school environment. Furthermore, $10.7 \%$ of articles suggest developing measures adapted to vulnerable groups, and 9.5\% highlight the need to apply disciplinary or legal measures. Lastly, $8.3 \%$ recommend integrating sexting into preventive programs about other associated risks.

In addition to these lines of action, only six articles set out specific initiatives to address sexting: the specific action under the 3rd Spanish Master Plan for the Coexistence and Improvement of School Safety; the Webrangers educational project; the action research project Image.me; a three-level strategic plan; the Sextorsion prevention course; and school assemblies about the risks of sexting.

The specific action established under the 3rd Spanish Master Plan for the Coexistence and Improvement of School Safety by the Spanish Government's Ministry of Education, Culture, and Sport; the Ministry of the Interior; and the Ministry of Public Health and Social Affairs contains presentations about the safety issues and risks associated with the use of the Internet to be developed alongside high school students. A Spanish civil guard officer, who is a specialist in New Technology and Risks, delivered an hourlong presentation about the possible risks of Internet use, especially those derived from using social networking sites, such as cyberbullying, grooming, and sexting. After the presentation, students completed an ad hoc questionnaire about their social network involvement. Information was gathered about their usage time or external supervision; the presentation content they found most interesting; and their personal opinions about the role of the Spanish civil guard officer. The impact of the activity on sexting was not evaluated (Martín et al., 2013).

The Webrangers education project is delivered in partnership with Google Inc., Palacký University Olomouc, and the NGO Google Education Group. It consists of a peer training program in which students interested in the topic are selected and given full-time training. This project covers risky Internet behaviors and the safe use of this tool to help prevent dangerous online conduct. Case studies are used to train students on the following core topics: cyberbullying, cyber-grooming, sexting, and skills for online interaction. After the training, students must create their own projects to raise awareness through Google Plus, Facebook, the project's Web site, and through workshops and activities for their colleagues and teachers. Information about their evaluation was not reported (Kopecký et al., 2015).

Image.me is an action research project about sexting prevention. It uses social theater with young people as preventive medical care, focusing on peer education through media and digital literacy. This combination encourages critical thinking and promotes collaborative work between classmates. These activities are part of a wider research project about theater and scientific communication led by the Catholic University of Milan. Social theater was used as a form of social care and online risk prevention. Three art scenes tailored to the project's target audience were chosen in an attempt to envisage how to address sexting effectively. One of the results was the creation of a pet-puppet used to get to know young people at schools, clubs, and other informal contexts. Videos were also made to raise young people's awareness about the 
Table 2 Lines of action identified to address sexting

1. Developing specific sexting programs
2. Promoting safe and healthy use of ICT, the Internet, and social
networks
3. Raising awareness about the consequences and risks of sexting
4. Incorporating information about sexting into sex education
programs

5. Training professionals

6. Promoting sexual ethics

7. Raising awareness about gender roles and stereotypes

8. Developing rules and implementing protocols

9. Encouraging coherence between the different parties involved

10. Working on the risk factors associated with the peer group

11. Considering the ideas and experiences of adolescents

12. Improving the school environment

13. Developing measures adapted to vulnerable groups

14. Applying disciplinary or legal measures, if needed

15. Incorporating sexting into preventive programs that tackle other associated risks
Description

The implementation of training/awareness activities and programs that address sexting in a specific way (definition, characteristics, reasons for participation, coping strategies, possible consequences, how to carry out safe sexting, etc.). These can be undertaken as face-to-face activities and/or through ICT

The development of activities and programs to provide strategies that encourage safe online behaviors

The need to discuss and analyze the specific consequences and risks that sexting can bring

The integration of sexting as another form of sexual behavior through digital media into training/awareness activities and sex education programs. These can be undertaken as face-to-face activities and/or through ICT

Continuous training and ongoing development for professionals who work with minors and young people

Fostering the necessary skills to make ethical decisions regarding intimate relationships

Analysis of gender roles and stereotypes, challenging the heteronormative rules of femininity and masculinity

Drawing up clear school rules that regulate possible conflictive situations related to new technologies and sexting, and designing protocols to help professionals know how to react and to tackle conflictive situations concerning sexting

The need to involve the education community as a whole in the actions taken to address sexting, as well as other institutions and society in general, whenever possible

Taking actions that address the importance of peer culture and the role of spectators

The need to build on the perceptions and practices held firsthand by adolescents, and to integrate them into the sexting-related actions to be taken. This can be carried out all together or in groups divided by gender

Encouraging positive, caring, and respectful relationships among the education community

The design and implementation of specific activities and strategies aimed at different groups who have shown a higher probability of being harmed, such as the LGBTQIA + community, ethnic minorities, students with a high risk of online victimization or greater impulsiveness, etc.

Establishing clear school behavioral sanctions that the education center deems negative and identifying criminal offense situations as cases where sexual content is created/distributed without consent

The incorporation of training strategies on sexting in the activities 7 and programs that address the different risks associated with this phenomenon presence of sexting in their communities. Social theater was also used to communicate the research findings at the end of the project. An art scene was designed and used to discuss the information gathered, making it easier to understand and engage with. Information on its evaluation was not reported (Ferrari et al., 2016).

The three-level strategic plan describes specific activities that schools can implement to tackle cyberbullying, sexting, and other risk behaviors on social media. The three-level model aims to meet the common needs of all students, the specific needs of some students, and other more specific and complex needs. Level 1 meets the general needs. It aims to provide a definition of the phenomenon and set out regulations planned for and by the education community, which also covers how to handle a conflictive sexting situation. In addition, as part of the school curriculum, the whole 
Table 3 Definition of sexting

\begin{tabular}{lll}
\hline & $\mathrm{N}$ & $\%$ \\
\hline Behavior & 29 & \\
Sending & 17 & 39.2 \\
Sharing/exchanging & 16 & 23.0 \\
Sending and receiving & 12 & 21.6 \\
Sending, receiving, and forwarding & & 16.2 \\
Type of content & 22 & \\
Pictures & 22 & 29.7 \\
Text messages, pictures, or videos & 21 & 29.7 \\
Text messages or videos & 5 & 28.4 \\
Does not specify & 2 & 6.8 \\
Pictures or videos & 2 & 2.7 \\
Text messages & & 2.7 \\
Degree of sexual explicitness & 36 & \\
Suggestive or explicit & 32 & 48.7 \\
Explicit & 6 & 43.2 \\
Does not specify & & 8.1 \\
\hline
\end{tabular}

institution should be given training about this phenomenon and its effects in order to safely address any kind of online behavior. Assessment twice a year is also important. Level 2 offers strategies for students at risk of becoming a bully or a victim. Prevention groups are formed to work on specific skills according to the potential participants' needs. Finally, Level 3 is delivered to students who are already actively involved in sexting and have more complex needs. In this case, intervention should focus on their direct needs, such as individual advice geared toward specific abilities, meetings with family members, and disciplinary and/or legal action. In general, the activities need to stress the importance of educating those involved about the Internet and its dangers. Information about its evaluation was not reported (Davis \& Schmidt, 2016).

The Sextorsion prevention course is delivered in high schools to teach students how to practice safe sexting. The learning methodology combines traditional lectures which provide an overall description of the topic with active learning, and directly engages students in the learning process. The course content includes the conceptualization and characteristics of sexting and sextortion, its associated risks, empathy toward the victim, legal consequences, safe practices, and measures and protocols to deal with the phenomenon. In particular, active learning was carried out by simulating different sexting and sextortion scenarios, encouraging students to be more independent and building their ability to search for relevant information related to sexting and sextortion. Different resources such as videos, group discussions, cases analyses and simulations, and group reflections were used. Regarding assessment, students answered a pre- and postcourse questionnaire about their knowledge of the topic and how satisfied they were with the course. However, the impact of the activity was not reported (Palop et al., 2016).

Finally, school assemblies were designed to educate high school pupils on the risks of sexting. The specific content of these assemblies was not provided. However, four years later, sexting patterns (except third-party forwarding) had not changed significantly. Most adolescents had exchanged sexually explicit pictures on their phones, and the common behavioral narratives remained very similar (Strassberg et al., 2017).

The previously stated lines of action and initiatives were joined by other notable recommendations for tackling this phenomenon:

Specifically, $19 \%$ of articles recommend staying away from scare tactics as a tool for intimidating young people; $11.9 \%$ recommend avoiding messages that promote the abstinence from and prohibition of sexting given their low level of effectiveness, adopting a more educational than authoritarian perspective; and 9.5\% recommend not blaming and judging the victim or those who partake in this practice. Furthermore, $9.5 \%$ of articles highlight the need to start taking action early on in school and in preadolescence, and 7.1\% recommend sexting assessment in schools to establish a baseline and to be able to promote strategies and actions based on the results obtained. Finally, $11.9 \%$ of articles recommend evaluating the impact of these strategies post-implementation to determine their effectiveness. Thus, the practices could be evidence based, promoting continuous improvement and adapting the strategies to the intervened context.

\section{Discussion}

Sexting has shaped itself into a new form of adolescent sexual exploration and expression (Schubert, 2014). However, it has also become a new challenge that professionals working with children need to understand in order to deal with it effectively (Bhat, 2018; Kopecký, 2012). This systematic review sought to gather information and describe the existing scientific evidence relative to the effective lines of action that address sexting, helping researchers and educators to design and evaluate sexting programs.

There is scientific evidence to support the need for sexting intervention. Specifically, these efforts must focus on the different ways in which this phenomenon is experienced and expressed: sending, receiving, and forwarding. The most commonly used sexting definition in the analyzed articles had sending as the most studied behavior. However, this definition does not cover the phenomenon's complexity. Third-party forwarding of sexual content also plays a highly significant role in understanding the consequences of sexting (Livingstone \& Görzig, 2014; Strassberg et al., 2017). Thus, it is important to include all three types of sexting behaviors 
(sending, receiving, and third-party forwarding) in order to analyze each one on its own and to be able to identify the necessary actions for each behavior.

Studies mainly focus on a particular geographical area (North America) and a specific subject area (Health), meaning that sexting research in other countries and in the educational field must also be encouraged. At a disciplinary level, the focus is primarily placed on the school setting (Livingstone \& Smith, 2014; Van Ouytsel et al., 2014b). Furthermore, only six of the 91 articles feature a specific intervention and just one article evaluates the impact of this action. This may be due to the fact that literature and educational campaigns have mainly focused on analyzing sexting as a problem, promoting abstinence, and condemning the practice. Consensual sexting as an intimate means of communication in line with contemporary communication methods must be accepted (Döring, 2014; Strassberg et al., 2017).

\section{What are the Types and Frequencies of Proposed Lines of Action for Sexting?}

Fifteen lines of action to address sexting effectively have been identified: (1) developing specific sexting programs; (2) promoting safe and healthy use of ICT, the Internet, and social networks; (3) raising awareness about the consequences and risks of sexting; (4) incorporating information about sexting into sex education programs; (5) training professionals; (6) promoting sexual ethics; (7) raising awareness about gender roles and stereotypes; (8) developing behavioral rules and implementing protocols; (9) encouraging coherence between the different parties involved; (10) working on the risk factors associated with the peer group; (11) considering the ideas and experiences of adolescents; (12) improving the school environment; (13) developing measures adapted to vulnerable groups; (14) applying disciplinary or legal measures, if needed; and (15) incorporating sexting into preventive programs that tackle other associated risks.

The development of specific programs that address sexting is the notable line of action. Undertaking both proactive and reactive activities is crucial (Albury et al., 2017). Some examples are: the use of case studies (e.g., Kopecký, 2015; Palop et al., 2016); discussions (e.g., Gregg et al., 2018; Siegle, 2010); educational campaigns, lectures, and workshops (e.g., Dobson \& Ringrose, 2016; Hinduja \& Patchin, 2012); the creation of information resources, a compilation of best practices (e.g., Döring, 2014; McEachern et al., 2012); real testimonies (Martín et al., 2013; Van Ouytsel, et al., 2014a, 2014b); debates (e.g., Dobson \& Ringrose, 2016; Van Ouytsel et al., 2015); and cross-curricular classroom projects (Laguado et al., 2018; Theodore, 2011).

Fostering a safe and healthy use of ICT, the Internet, and social networks is also noteworthy. Because adolescents who use their cell phones as their main Internet connection and spend more time connected are most likely to receive sexting requests (Atwood et al., 2017), it is important to teach them how to use technology appropriately. This training should cover personal expectations about digital privacy (e.g., Albury et al., 2017; Soriano-Ayala \& González-Jiménez, 2014); control over personal data on the Internet (e.g., Diliberto \& Mattey, 2009; Patrick et al., 2015); safe online behaviors (e.g., Mura et al., 2014; O’ Keeffe, 2016); and knowledge of rights and responsibilities when it comes to digital technology (e.g., Gámez-Guadix et al., 2017; Uhler \& Smith, 2012).

Efforts to incorporate sexting into sex education programs is also a fundamental part of handling this phenomenon, as sexting may be seen as a way to maintain intimate communication with a partner in a healthy relationship (Van Ouytsel, et al., 2014a, 2014b). On many occasions, sexting is used to show a romantic or sexual interest in another person; to build new emotional bonds; to delve deeper into the development of their sexual identity; and merely as another form of sexual activity in a long-distance relationship (Döring, 2014; Walker et al., 2011). Thus, addressing sexting as an integral component of sex education programs provides young people with information about the phenomenon and how to tackle it safely, instead of evading it or encouraging the negative views held by many adolescents about sexting. Given the correlation between sexting and traditional or digital risks, such as bullying and cyberbullying (e.g., Rodríguez-Castro et al., 2017; Woodward et al., 2017), introducing sexting into preventive programs that address other associated risksadopting an integrated approach-is also recommended (e.g., Dake et al., 2012; West et al., 2014).

The promotion of sexual ethics is also linked to sex education, namely specific and key aspects that address sexting effectively. Its focus is on developing the necessary skills to build and maintain an intimate and ethical relationship (Walker et al., 2011), such as preventing coercion and pressure in a loving sexual relationship; fostering reflection on the importance of proper consent and real respect for a partner or intimate companion; and maintaining a critical attitude toward the exchange of non-consensual sexual content (e.g., Albury et al., 2017; Wurtele \& Miller-Perrin, 2014). In terms of sexual ethics, gender roles and stereotypes must also be considered. Acknowledging the cultural norms and values that underpin social behavior is essential to successfully addressing the phenomena which play out in personal interactions. Thus, it is necessary to understand and question the heteronormative values associated with femininity and masculinity which form part of the digital culture and to determine the dynamics and roles played by individuals who engage in sexting (e.g., Karaian, 2014; Wood et al., 2015). It is particularly important to involve young people in analyzing the power imbalance between genders and the double sexual standard and to avoid the use of stereotypes and blaming 
women, in the strategies used to address sexting (e.g., Döring, 2014; Van Ouytsel et al., 2014a).

Raising awareness about the impact and risks of sexting is also important. Sexting can lead to undesired consequences, which can turn into problematic scenarios alongside other risks such as bullying and cyberbullying (Frankel et al., 2018; Medrano et al., 2018; Ringrose et al., 2012). For this reason, young people need to be aware of the risks. However, we need to remember that, for some people, sexting is a romantic and enriching part of their relationship, although it can be dangerous (Ybarra \& Mitchell, 2014). Furthermore, some studies suggest that many adolescents already have a clear picture of the consequences this phenomenon entails, and steps to ban and warn against sexting alone do not work to prevent the potential consequences (Lim et al., 2016). In this systematic review, only one evaluation of the proposed lines of action has been observed, which focuses on the lack of efficacy behind this strategy. It does, however, seem to reduce the extent to which this type of content is forwarded without consent, yet it does not effectively avert other possible negative consequences linked to sexting (Strassberg et al., 2017).

Providing training to professionals who work with young people would also help them feel more capable of addressing sexting. It would equip them with the skills to react properly to difficult situations brought about by sexting. Thus, there is a need to stay up-to-date with the apps that adolescents use; discuss sexuality in a professional way (e.g., Van Ouytsel et al., 2014a, 2014b); have the resources to deal with this reality (e.g., Brown et al., 2009); know what sexting is and what drives adolescents to participate in it (e.g., Frankel et al., 2018); and be aware of the ensuing legal and moral obligations (e.g., Schubert \& Wurf, 2014). From this perspective, sexting regulations and protocols should be developed in order to provide professionals with a common ground for dealing with this phenomenon. They must be given the necessary tools to act consistently and appropriately, making it easier for pupils to understand the differences between correct and incorrect sexting behavior (e.g., Krieger, 2017; Theodore, 2011). From this perspective and taking into account the other strategies, the adoption of disciplinary or legal measures is crucial in cases where this type of consent is shared non-consensually and where aggressive attitudes are exhibited (e.g., Davis \& Schmidt, 2016; Russo \& Arndt, 2010); for example, in cases where sexting is associated with bullying (e.g., Van Ouytsel et al., 2014b).

Involvement by the entire education community and potential participants is a key aspect when it comes to fostering coherent and stable actions across the different settings that young people move within and between, thus joining efforts and strategies to tackle this phenomenon (e.g., Frankel et al., 2018).

The peer group risk factors for sexting also play an important role among adolescents. During adolescence, social status is particularly important (Chalfen, 2009; Ling, 2004), and sexting offers an opportunity to become more popular (Gewirtz-Meydan et al., 2018). It may be seen as a strategic move for adolescents to gain popularity among peers (Baumgartner et al., 2015). Thus, encouraging reflection on social pressure and the need for popularity, as well as being critical toward the content received via the Internet, is fundamental (e.g., Ahern \& Mechling, 2013; Wolak et al., 2012). Similarly, the false beliefs that adolescents hold about sexting and the notion that all young people engage in this mainstream phenomenon should also be challenged. Adolescents believe that the messages circulating within their immediate surroundings and the media influence their predisposition to develop sexting attitudes, viewing this phenomenon as a normal practice (Smith et al., 2014). The perceptions and experiences of adolescents also make for a good starting point according to the literature, allowing us to understand the whys and hows of their behavior in order to respond to young people's actual needs (e.g., Livingstone \& Görzig, 2014; Murray, 2014).

Efforts to improve the school environment are also reported to have a positive effect on resolving difficult situations associated with sexting. Some examples of good coexistence practices include: maintaining high expectations for student performance; offering pupils the opportunity to participate and contribute in class, at school, and in the education community (e.g., West et al., 2014); implementing peer education/coaching (e.g., Ferrari et al., 2016; Siegle, 2010); and promoting student safety at school, for example, by adopting measures that encourage them to report worrying cases of sexting and other negative behaviors without fear of retaliation (e.g., Gregg et al., 2018; McEachern et al., 2012). Furthermore, when responding to the needs of young people, it is important to cater for diversity and to adopt specific measures that acknowledge, address, and integrate the particularities of vulnerable groups (e.g., Brown et al., 2009; Livingstone \& Görzig, 2014).

Finally, in addition to the discussed lines of action, recommendations are made to address this phenomenon early on in the school cycle, likely because the use of virtual networks increases gradually until the age of 13 , when it comes into more general use (Garmendia et al., 2016). Furthermore, sexting is characterized by the developmental stage of adolescents' first romantic or sexual relationships (Fox \& Warber, 2013; Van Ouytsel et al., 2016), which highlights the importance of educating young people and relying upon strategies suitable for minors at an early age. Fear tactics and abstinence should also be avoided, as they can make young people increasingly more interested in this practice, without giving them alternative approaches (Gómez \& Ayala, 2014). In addition, they do not accurately represent the sexual reality of our contemporary society, preventing us from suggesting strategies to dissuade the negative consequences of sexting 
among young people (e.g., Döring, 2014). It is also advisable not to judge the victims and individuals who engage in this practice, but rather those who inflict harm and forward content without consent (e.g., Wood et al., 2015). Lastly, evaluation plays a significant role when addressing sexting in order to understand the reality within the corresponding context (e.g., Barrense-Dias et al., 2017; Davis \& Schmidt, 2016) and to promote evidence-based practices. Drawing on measurable objectives and considering the definition used is also important. This would enable us to determine the impact and effectiveness of the strategies, so they could act as support mechanisms for professionals working with minors on a daily basis (e.g., Lim et al., 2016; Livingstone \& Smith, 2014).

This systematic review does present some limitations. Studies addressing this topic may not have been considered for the following reasons: Sexting was identified through another term; sexting was implicitly covered in intervention programs about other phenomena; or the full article could not be accessed. It is also possible that effective actions are still under development, currently at the "to be published" stage or on the lookout to be published. Future research could build on this review by including studies from other databases, and more comparative studies and further analyses into the nature and characteristics of sexting from an educational point of view would prove useful. There is also a need to evaluate the strategies and actions used to address sexting, with the aim to design and implement evidence-based initiatives that equip schools and teaching staff with effective tools to prevent and tackle the potential risks associated with this phenomenon.

\footnotetext{
${ }^{1}$ The numbers in "lines of action" refer to the numbers in "areas of action" to which they correspond.
}

Funding This work has been developed in the framework of the Project "Interpersonal violence in adolescence: a new generation of evidencebased interventions" (Prevención de la violencia interpersonal en la adolescencia: una nueva generación de intervenciones basadas en la evidencia) [PSI2017-86723-R] funded by the National Research Plan (Government of Spain).

\section{Declarations}

Conflict of interest The authors report no conflicts of interest.

Open Access This article is licensed under a Creative Commons Attribution 4.0 International License, which permits use, sharing, adaptation, distribution and reproduction in any medium or format, as long as you give appropriate credit to the original author(s) and the source, provide a link to the Creative Commons licence, and indicate if changes were made. The images or other third party material in this article are included in the article's Creative Commons licence, unless indicated otherwise in a credit line to the material. If material is not included in the article's Creative Commons licence and your intended use is not permitted by statutory regulation or exceeds the permitted use, you will need to obtain permission directly from the copyright holder. To view a copy of this licence, visit http://creativecommons.org/licenses/by/4.0/. 


\section{Appendix: General information on the articles included}

\begin{tabular}{|c|c|c|c|c|c|c|c|}
\hline No. & Author(s) & Country & Definition of sexting & $\begin{array}{l}\text { Evidence of } \\
\text { action }\end{array}$ & Areas of action & Lines of action & Evaluation \\
\hline 1 & $\begin{array}{l}\text { Diliberto \& } \\
\text { Mattey (2009) }\end{array}$ & USA & $\begin{array}{l}\text { Sending, receiving } \\
\text { and forwarding } \\
\text { sexually sugges- } \\
\text { tive pictures or } \\
\text { text messages on } \\
\text { mobile phones }\end{array}$ & $\begin{array}{l}\text { Proposes spe- } \\
\text { cific strategies }\end{array}$ & $\begin{array}{l}\text { 1. School } \\
\text { 3. Family through } \\
\text { school }\end{array}$ & $\begin{array}{l}\text { 1. Promoting safe and healthy } \\
\text { use of ICT, the Internet and } \\
\text { social networks } \\
\text { 1, 3. Developing specific sex- } \\
\text { ting programs } \\
\text { 1, 3. Raising awareness about } \\
\text { the consequences and risks } \\
\text { of sexting }\end{array}$ & No \\
\hline 2 & Manzo (2009) & USA & $\begin{array}{l}\text { Sharing/exchanging } \\
\text { sexually explicit/ } \\
\text { suggestive pictures } \\
\text { on digital devices }\end{array}$ & $\begin{array}{l}\text { Proposes spe- } \\
\text { cific strategies }\end{array}$ & $\begin{array}{l}\text { 1. School } \\
\text { 3. Family through } \\
\text { school }\end{array}$ & $\begin{array}{l}\text { 1. Training professionals } \\
1,3 \text {. Raising awareness about } \\
\text { the consequences and risks } \\
\text { of sexting }\end{array}$ & No \\
\hline 3 & $\begin{array}{l}\text { Brown et al. } \\
\text { (2009) }\end{array}$ & USA & $\begin{array}{l}\text { Sharing/exchanging } \\
\text { sexually sugges- } \\
\text { tive or explicit text } \\
\text { messages, pictures } \\
\text { on social networks } \\
\text { or mobile phones }\end{array}$ & $\begin{array}{l}\text { Proposes spe- } \\
\text { cific strategies }\end{array}$ & $\begin{array}{l}\text { 1. School } \\
\text { 3. Family through } \\
\text { school }\end{array}$ & $\begin{array}{l}\text { 1. Developing measures } \\
\text { adapted to vulnerable groups } \\
\text { 1. Promoting safe and healthy } \\
\text { use of ICT, the Internet and } \\
\text { social networks } \\
\text { 1. Training professionals } \\
\text { 3. Incorporating information } \\
\text { about sexting into sex educa- } \\
\text { tion programs }\end{array}$ & No \\
\hline 4 & Boucek (2009) & USA & $\begin{array}{l}\text { Sending sexually } \\
\text { suggestive or } \\
\text { explicit pictures } \\
\text { on mobile phones, } \\
\text { computers or } \\
\text { another digital } \\
\text { device }\end{array}$ & $\begin{array}{l}\text { Proposes spe- } \\
\text { cific strategies }\end{array}$ & $\begin{array}{l}\text { 1. School } \\
\text { 7. Legal advice } \\
\text { 9. Technology } \\
\text { experts }\end{array}$ & $\begin{array}{l}\text { 1, 7, 9. Developing rules and } \\
\text { implementing protocols }\end{array}$ & No \\
\hline 5 & Taylor (2009) & USA & $\begin{array}{l}\text { Sending sexually } \\
\text { suggestive or } \\
\text { explicit pictures, } \\
\text { generally on } \\
\text { mobile phones }\end{array}$ & $\begin{array}{l}\text { Proposes spe- } \\
\text { cific strategies }\end{array}$ & $\begin{array}{l}\text { 1. School } \\
\text { 3. Family through } \\
\text { school } \\
\text { 8. Law enforce- } \\
\text { ment }\end{array}$ & $\begin{array}{l}\text { 1. Training professionals } \\
1,3,8 \text {. Raising awareness } \\
\text { about the consequences and } \\
\text { risks of sexting }\end{array}$ & No \\
\hline 6 & Siegle (2010) & USA & $\begin{array}{l}\text { Sending sexually } \\
\text { suggestive or } \\
\text { explicit pictures } \\
\text { on the Internet or } \\
\text { mobile phones }\end{array}$ & $\begin{array}{l}\text { Proposes spe- } \\
\text { cific strategies }\end{array}$ & $\begin{array}{l}\text { 1. School } \\
\text { 3. Family through } \\
\text { school } \\
\text { 7. Legal advice }\end{array}$ & $\begin{array}{l}\text { 1. Promoting safe and healthy } \\
\text { use of ICT, the Internet and } \\
\text { social networks } \\
\text { 1. Improving the school envi- } \\
\text { ronment } \\
\text { 1, } 7 \text {. Developing rules and } \\
\text { implementing protocols } \\
\text { 1. Applying disciplinary or } \\
\text { legal measures } \\
\text { Training professionals } \\
\text { 1, } 3 \text {. Developing specific sex- } \\
\text { ting programs } \\
\text { 1. Encouraging coherence } \\
\text { between the different parties } \\
\text { involved }\end{array}$ & No \\
\hline
\end{tabular}




\begin{tabular}{|c|c|c|c|c|c|c|c|}
\hline No. & Author(s) & Country & Definition of sexting & $\begin{array}{l}\text { Evidence of } \\
\text { action }\end{array}$ & Areas of action & Lines of action & Evaluation \\
\hline$\overline{7}$ & $\begin{array}{l}\text { Russo \& Arndt } \\
\text { (2010) }\end{array}$ & USA & $\begin{array}{l}\text { Sending sexually } \\
\text { explicit pictures } \\
\text { or text messages } \\
\text { on mobile phones } \\
\text { or other mobile } \\
\text { devices }\end{array}$ & $\begin{array}{l}\text { Proposes spe- } \\
\text { cific strategies }\end{array}$ & $\begin{array}{l}\text { 1. School } \\
\text { 3. Family through } \\
\text { school }\end{array}$ & $\begin{array}{l}\text { 1. Developing rules and imple- } \\
\text { menting protocols } \\
\text { 1. Training professionals } \\
\text { 1, 3. Developing specific sex- } \\
\text { ting programs } \\
\text { 1, 3. Raising awareness about } \\
\text { the consequences and risks } \\
\text { of sexting } \\
\text { 1. Encouraging coherence } \\
\text { between the different parties } \\
\text { involved } \\
\text { 1. Applying disciplinary or } \\
\text { legal measures } \\
\text { 1. Promoting safe and healthy } \\
\text { use of ICT, the Internet and } \\
\text { social networks }\end{array}$ & No \\
\hline 8 & $\begin{array}{l}\text { Skarbek \& } \\
\text { Mooney } \\
(2011)\end{array}$ & USA & $\begin{array}{l}\text { Sending sexually } \\
\text { explicit pictures } \\
\text { or messages on } \\
\text { mobile phones }\end{array}$ & $\begin{array}{l}\text { Recommends } \\
\text { acting, but } \\
\text { does not pro- } \\
\text { vide any spe- } \\
\text { cific strategy }\end{array}$ & $\begin{array}{l}\text { 1. School } \\
\text { 2. Family }\end{array}$ & & No \\
\hline 9 & $\begin{array}{l}\text { Walker et al. } \\
\text { (2011) }\end{array}$ & Australia & $\begin{array}{l}\text { Sending and receiv- } \\
\text { ing sexually } \\
\text { explicit pictures on } \\
\text { mobile phones }\end{array}$ & $\begin{array}{l}\text { Proposes spe- } \\
\text { cific strategies }\end{array}$ & 1. School & $\begin{array}{l}\text { 1. Promoting sexual ethics } \\
\text { 1. Considering the ideas and } \\
\text { experiences of adolescents }\end{array}$ & No \\
\hline 10 & $\begin{array}{l}\text { Segool \& Crespi } \\
\quad(2011)\end{array}$ & USA & -- & $\begin{array}{l}\text { Recommends } \\
\text { acting, but } \\
\text { does not pro- } \\
\text { vide any spe- } \\
\text { cific strategy }\end{array}$ & 1. School & & No \\
\hline 11 & Dessoff (2011) & USA & -- & $\begin{array}{l}\text { Recommends } \\
\text { acting, but } \\
\text { does not pro- } \\
\text { vide any spe- } \\
\text { cific strategy }\end{array}$ & 1. School & & No \\
\hline 12 & Theodore (2011) & USA & $\begin{array}{l}\text { Sending sexually } \\
\text { suggestive or } \\
\text { explicit pictures } \\
\text { or messages on } \\
\text { mobile phones or } \\
\text { the Internet }\end{array}$ & $\begin{array}{l}\text { Proposes spe- } \\
\text { cific strategies }\end{array}$ & 1. School & $\begin{array}{l}\text { 1. Raising awareness about the } \\
\text { consequences and risks of } \\
\text { sexting } \\
\text { 1. Incorporating information } \\
\text { about sexting into sex educa- } \\
\text { tion programs } \\
\text { 1. Considering the ideas and } \\
\text { experiences of adolescents } \\
\text { 1. Developing specific sexting } \\
\text { programs } \\
\text { 1. Developing rules and imple- } \\
\text { menting protocols } \\
\text { 1. Applying disciplinary or } \\
\text { legal measures }\end{array}$ & No \\
\hline 13 & $\begin{array}{l}\text { Rice et al. } \\
\quad(2012)\end{array}$ & USA & $\begin{array}{l}\text { Sending and receiv- } \\
\text { ing sexually } \\
\text { explicit pictures } \\
\text { or messages on } \\
\text { mobile phones }\end{array}$ & $\begin{array}{l}\text { Proposes spe- } \\
\text { cific strategies }\end{array}$ & 1. School & $\begin{array}{l}\text { 1. Incorporating information } \\
\text { about sexting into sex educa- } \\
\text { tion programs } \\
\text { 1. Promoting safe and healthy } \\
\text { use of ICT, the Internet and } \\
\text { social networks } \\
\text { 1. Promoting sexual ethics } \\
\text { 1. Developing measures } \\
\text { adapted to vulnerable groups }\end{array}$ & No \\
\hline
\end{tabular}




\begin{tabular}{|c|c|c|c|c|c|c|c|}
\hline No. & Author(s) & Country & Definition of sexting & $\begin{array}{l}\text { Evidence of } \\
\text { action }\end{array}$ & Areas of action & Lines of action & Evaluation \\
\hline$\overline{14}$ & $\begin{array}{l}\text { Temple et al. } \\
(2012)\end{array}$ & USA & $\begin{array}{l}\text { Sending sexually } \\
\text { explicit pictures }\end{array}$ & $\begin{array}{l}\text { Proposes spe- } \\
\text { cific strategies }\end{array}$ & 4. Health & $\begin{array}{l}\text { 4. Incorporating information } \\
\text { about sexting into sex educa- } \\
\text { tion programs } \\
\text { 4. Raising awareness about the } \\
\text { consequences and risks of } \\
\text { sexting }\end{array}$ & No \\
\hline 15 & Kopecký (2012) & $\begin{array}{l}\text { Czech } \\
\text { Republic }\end{array}$ & $\begin{array}{l}\text { Sharing/exchanging } \\
\text { sexually explicit } \\
\text { text messages, pic- } \\
\text { tures or videos by } \\
\text { electronic means }\end{array}$ & $\begin{array}{l}\text { Proposes spe- } \\
\text { cific strategies }\end{array}$ & 1. School & $\begin{array}{l}\text { 1. Developing specific sexting } \\
\text { programs }\end{array}$ & No \\
\hline 16 & $\begin{array}{l}\text { Albury \& Craw- } \\
\text { ford (2012) }\end{array}$ & Australia & $\begin{array}{l}\text { Sending sexually } \\
\text { suggestive or } \\
\text { explicit pictures on } \\
\text { mobile phones }\end{array}$ & $\begin{array}{l}\text { Proposes spe- } \\
\text { cific strategies }\end{array}$ & 6. Policies & $\begin{array}{l}\text { 6. Promoting sexual ethics } \\
\text { 6. Considering the ideas and } \\
\text { experiences of adolescents }\end{array}$ & No \\
\hline 17 & $\begin{array}{l}\text { Strasburger et al. } \\
\text { (2012) }\end{array}$ & USA & $\begin{array}{l}\text { Sharing/exchanging } \\
\text { sexually explicit } \\
\text { pictures on mobile } \\
\text { phones }\end{array}$ & $\begin{array}{l}\text { Proposes spe- } \\
\text { cific strategies }\end{array}$ & 1. School & $\begin{array}{l}\text { 1. Incorporating information } \\
\text { about sexting into sex educa- } \\
\text { tion programs } \\
\text { 1. Promoting safe and healthy } \\
\text { use of ICT, the Internet and } \\
\text { social networks } \\
\text { 1. Developing rules and imple- } \\
\text { menting protocols }\end{array}$ & No \\
\hline 18 & $\begin{array}{l}\text { McEachern et al. } \\
\text { (2012) }\end{array}$ & USA & $\begin{array}{l}\text { Sending sexually } \\
\text { explicit pictures } \\
\text { or messages using } \\
\text { digital and elec- } \\
\text { tronic devices }\end{array}$ & $\begin{array}{l}\text { Proposes spe- } \\
\text { cific strategies }\end{array}$ & $\begin{array}{l}\text { 1. School } \\
\text { 2. Family } \\
\text { 3. Family through } \\
\text { school } \\
\text { 6. Policies } \\
\text { 8. Law enforce- } \\
\text { ment }\end{array}$ & $\begin{array}{l}\text { 1. Applying disciplinary or } \\
\text { legal measures } \\
\text { 1, 3. Developing specific sex- } \\
\text { ting programs } \\
\text { 1. Improving the school envi- } \\
\text { ronment } \\
\text { 1. Developing rules and imple- } \\
\text { menting protocols } \\
\text { 1. Raising awareness about the } \\
\text { consequences and risks of } \\
\text { sexting } \\
\text { 1. Training professionals } \\
\text { 1, } 2,6,8 \text {. Encouraging coher- } \\
\text { ence between the different } \\
\text { parties involved } \\
\text { 1. Promoting safe and healthy } \\
\text { use of ICT, the Internet and } \\
\text { social networks }\end{array}$ & No \\
\hline 19 & $\begin{array}{l}\text { Dake et al. } \\
\text { (2012) }\end{array}$ & USA & -- & $\begin{array}{l}\text { Proposes spe- } \\
\text { cific strategies }\end{array}$ & $\begin{array}{l}\text { 1. School } \\
\text { 2. Family } \\
\text { 4. Health }\end{array}$ & $\begin{array}{l}\text { 1, } 2,4 . \text { Developing specific } \\
\text { sexting programs } \\
\text { 1. Incorporating information } \\
\text { about sexting into sex educa- } \\
\text { tion programs }\end{array}$ & No \\
\hline 20 & $\begin{array}{l}\text { Uhler \& Smith } \\
\text { (2012) }\end{array}$ & USA & -- & $\begin{array}{l}\text { Proposes spe- } \\
\text { cific strategies }\end{array}$ & 1. School & $\begin{array}{l}\text { 1. Applying disciplinary or } \\
\text { legal measures }\end{array}$ & No \\
\hline 21 & Sadhu (2012) & USA & -- & $\begin{array}{l}\text { Proposes spe- } \\
\text { cific strategies }\end{array}$ & $\begin{array}{l}\text { 4. Health } \\
5 \text {. Family through } \\
\text { health }\end{array}$ & $\begin{array}{l}\text { 4. Training professionals } \\
\text { 4, 5. Developing specific sex- } \\
\text { ting programs } \\
\text { 4, 5. Raising awareness about } \\
\text { the consequences and risks } \\
\text { of sexting }\end{array}$ & No \\
\hline
\end{tabular}




\begin{tabular}{|c|c|c|c|c|c|c|c|}
\hline No. & Author(s) & Country & Definition of sexting & $\begin{array}{l}\text { Evidence of } \\
\text { action }\end{array}$ & Areas of action & Lines of action & Evaluation \\
\hline$\overline{22}$ & $\begin{array}{l}\text { Wolak et al. } \\
(2012)\end{array}$ & USA & $\begin{array}{l}\text { Sending sexually } \\
\text { explicit pictures }\end{array}$ & $\begin{array}{l}\text { Recommends } \\
\text { acting, but } \\
\text { does not pro- } \\
\text { vide any spe- } \\
\text { cific strategy }\end{array}$ & $\begin{array}{l}\text { 1. School } \\
\text { 2. Family } \\
\text { 4. Health } \\
\text { 6. Policies }\end{array}$ & & No \\
\hline 23 & $\begin{array}{l}\text { Mitchell et al. } \\
\text { (2012) }\end{array}$ & USA & $\begin{array}{l}\text { Sending, receiving } \\
\text { and forwarding } \\
\text { sexually sugges- } \\
\text { tive or explicit } \\
\text { pictures, videos } \\
\text { or text messages } \\
\text { on mobile phones, } \\
\text { the Internet or by } \\
\text { other electronic } \\
\text { means }\end{array}$ & $\begin{array}{l}\text { Proposes spe- } \\
\text { cific strategies }\end{array}$ & 1. School & $\begin{array}{l}\text { 1. Raising awareness about the } \\
\text { consequences and risks of } \\
\text { sexting } \\
\text { 1. Developing specific sexting } \\
\text { programs }\end{array}$ & No \\
\hline 24 & $\begin{array}{l}\text { Hinduja \& } \\
\quad \text { Patchin (2012) }\end{array}$ & USA & -- & $\begin{array}{l}\text { Proposes spe- } \\
\text { cific strategies }\end{array}$ & 1. School & $\begin{array}{l}\text { 1. Improving the school envi- } \\
\text { ronment } \\
\text { 1. Developing rules and imple- } \\
\text { menting protocols }\end{array}$ & No \\
\hline 25 & $\begin{array}{l}\text { Ahern \& Mech- } \\
\text { ling (2013) }\end{array}$ & USA & $\begin{array}{l}\text { Sending, receiving } \\
\text { and forwarding } \\
\text { sexually sugges- } \\
\text { tive or explicit } \\
\text { pictures or text } \\
\text { messages on } \\
\text { mobile phones }\end{array}$ & $\begin{array}{l}\text { Proposes spe- } \\
\text { cific strategies }\end{array}$ & $\begin{array}{l}\text { 2. Family } \\
\text { 4. Health } \\
\text { 10. All areas }\end{array}$ & $\begin{array}{l}\text { 2, 10. Encouraging coherence } \\
\text { between the different parties } \\
\text { involved } \\
\text { 4. Raising awareness about the } \\
\text { consequences and risks of } \\
\text { sexting } \\
\text { 4. Promoting safe and healthy } \\
\text { use of ICT, the Internet and } \\
\text { social networks } \\
\text { 4. Working on the risk factors } \\
\text { associated with the peer } \\
\text { group }\end{array}$ & No \\
\hline 26 & $\begin{array}{l}\text { Fenaughty \& } \\
\text { Harré (2013) }\end{array}$ & $\begin{array}{l}\text { New Zea- } \\
\text { land }\end{array}$ & $\begin{array}{l}\text { Sharing/exchanging } \\
\text { sexual material via } \\
\text { electronic means }\end{array}$ & $\begin{array}{l}\text { Proposes spe- } \\
\text { cific strategies }\end{array}$ & 1. School & $\begin{array}{l}\text { 1. Promoting safe and healthy } \\
\text { use of ICT, the Internet and } \\
\text { social networks } \\
\text { 1. Raising awareness about the } \\
\text { consequences and risks of } \\
\text { sexting }\end{array}$ & No \\
\hline 27 & $\begin{array}{l}\text { Martín et al. } \\
\text { (2013) }\end{array}$ & Spain & -- & $\begin{array}{l}\text { Presents inter- } \\
\text { vention }\end{array}$ & 1. School & $\begin{array}{l}\text { 1. Developing specific sexting } \\
\text { programs } \\
\text { 1. Promoting safe and healthy } \\
\text { use of ICT, the Internet and } \\
\text { social networks }\end{array}$ & Yes \\
\hline 28 & $\begin{array}{l}\text { Strassberg et al. } \\
\text { (2013) }\end{array}$ & USA & $\begin{array}{l}\text { Sending and receiv- } \\
\text { ing sexually } \\
\text { explicit pictures on } \\
\text { mobile phones }\end{array}$ & $\begin{array}{l}\text { Proposes spe- } \\
\text { cific strategies }\end{array}$ & $\begin{array}{l}\text { 1. School } \\
\text { 2. Family } \\
\text { 6. Policies } \\
\text { 8. Law enforce- } \\
\text { ment }\end{array}$ & $\begin{array}{l}1,2,6,8 \text {. Training profes- } \\
\text { sionals } \\
\text { 1. Developing specific sexting } \\
\text { programs } \\
\text { 1. Promoting safe and healthy } \\
\text { use of ICT, the Internet and } \\
\text { social networks }\end{array}$ & No \\
\hline 29 & $\begin{array}{l}\text { Van Ouytsel } \\
\text { et al. (2014a) }\end{array}$ & Belgium & $\begin{array}{l}\text { Sending sexually } \\
\text { suggestive or } \\
\text { explicit pictures } \\
\text { on the Internet or } \\
\text { mobile phones }\end{array}$ & $\begin{array}{l}\text { Proposes spe- } \\
\text { cific strategies }\end{array}$ & 1. School & $\begin{array}{l}\text { 1. Applying disciplinary or } \\
\text { legal measures }\end{array}$ & No \\
\hline
\end{tabular}




\begin{tabular}{|c|c|c|c|c|c|c|c|}
\hline No. & Author(s) & Country & Definition of sexting & $\begin{array}{l}\text { Evidence of } \\
\text { action }\end{array}$ & Areas of action & Lines of action & Evaluation \\
\hline$\overline{30}$ & $\begin{array}{l}\text { Wurtele \& } \\
\text { Miller-Perrin } \\
\text { (2014) }\end{array}$ & USA & $\begin{array}{l}\text { Sending sexually } \\
\text { suggestive and } \\
\text { explicit pictures, } \\
\text { videos and text } \\
\text { messages via } \\
\text { mobile phones or } \\
\text { web cams }\end{array}$ & $\begin{array}{l}\text { Proposes spe- } \\
\text { cific strategies }\end{array}$ & $\begin{array}{l}\text { 1. School } \\
\text { 2. Family } \\
\text { 3. Family through } \\
\text { school } \\
\text { 4. Health } \\
\text { 6. Policies } \\
\text { 9. Technology } \\
\text { experts }\end{array}$ & $\begin{array}{l}\text { 1. Promoting safe and healthy } \\
\text { use of ICT, the Internet and } \\
\text { social networks } \\
\text { 1. Developing specific sexting } \\
\text { programs } \\
\text { 1. Working on the risk factors } \\
\text { associated with the peer } \\
\text { group } \\
\text { 1. Raising awareness about the } \\
\text { consequences and risks of } \\
\text { sexting } \\
\text { 1. Considering the ideas and } \\
\text { experiences of adolescents } \\
\text { 1. Developing measures } \\
\text { adapted to vulnerable groups } \\
\text { 1. Promoting sexual ethics } \\
\text { 1. Incorporating sexting into } \\
\text { preventive programs that } \\
\text { tackle other associated risks } \\
\text { 1. Incorporating information } \\
\text { about sexting into sex educa- } \\
\text { tion programs } \\
\text { 1, 2, } 3,4,6,9 \text {. Encouraging } \\
\text { coherence between the differ- } \\
\text { ent parties involved }\end{array}$ & $\begin{array}{r}\text { Recom- } \\
\text { mends }\end{array}$ \\
\hline 31 & Kenny (2014) & USA & -- & $\begin{array}{l}\text { Proposes spe- } \\
\text { cific strategies }\end{array}$ & $\begin{array}{l}\text { 1. School } \\
\text { 2. Family }\end{array}$ & $\begin{array}{l}\text { 1, } 2 . \text { Encouraging coherence } \\
\text { between the different parties } \\
\text { involved } \\
\text { 1. Incorporating information } \\
\text { about sexting into sex educa- } \\
\text { tion programs } \\
\text { 1. Developing specific sexting } \\
\text { programs }\end{array}$ & $\begin{array}{l}\text { Recom- } \\
\text { mends }\end{array}$ \\
\hline 32 & $\begin{array}{l}\text { Livingstone \& } \\
\text { Görzig (2014) }\end{array}$ & $\begin{array}{l}\text { United } \\
\text { Kingdom }\end{array}$ & $\begin{array}{l}\text { Sending and receiv- } \\
\text { ing sexually sug- } \\
\text { gestive or explicit } \\
\text { pictures or text } \\
\text { messages on the } \\
\text { Internet }\end{array}$ & $\begin{array}{l}\text { Proposes spe- } \\
\text { cific strategies }\end{array}$ & $\begin{array}{l}\text { 1. School } \\
\text { 3. Family through } \\
\text { school }\end{array}$ & $\begin{array}{l}\text { 1. Developing measures } \\
\text { adapted to vulnerable groups } \\
\text { 1. Raising awareness about } \\
\text { gender roles and stereotypes } \\
\text { 1, 3. Promoting sexual ethics } \\
\text { 1. Developing specific sexting } \\
\text { programs } \\
\text { 1. Incorporating information } \\
\text { about sexting into sex educa- } \\
\text { tion programs } \\
\text { 1. Considering the ideas and } \\
\text { experiences of adolescents }\end{array}$ & No \\
\hline 33 & $\begin{array}{l}\text { Houck et al. } \\
\text { (2014) }\end{array}$ & USA & $\begin{array}{l}\text { Sending sexually } \\
\text { explicit pictures or } \\
\text { messages }\end{array}$ & $\begin{array}{l}\text { Proposes spe- } \\
\text { cific strategies }\end{array}$ & $\begin{array}{l}\text { 1. School } \\
\text { 2. Family } \\
\text { 4. Health } \\
\text { 7. Family through } \\
\text { health }\end{array}$ & $\begin{array}{l}1,2,4,7 \text {. Promoting safe and } \\
\text { healthy use of ICT, the Inter- } \\
\text { net and social networks } \\
\text { 4. Incorporating information } \\
\text { about sexting into sex educa- } \\
\text { tion programs }\end{array}$ & No \\
\hline
\end{tabular}




\begin{tabular}{|c|c|c|c|c|c|c|c|}
\hline No. & Author(s) & Country & Definition of sexting & $\begin{array}{l}\text { Evidence of } \\
\text { action }\end{array}$ & Areas of action & Lines of action & Evaluation \\
\hline$\overline{34}$ & Döring ( 2014) & Germany & $\begin{array}{l}\text { Sharing/exchanging } \\
\text { sexual pictures on } \\
\text { mobile phones or } \\
\text { the Internet }\end{array}$ & $\begin{array}{l}\text { Proposes spe- } \\
\text { cific strategies }\end{array}$ & $\begin{array}{l}\text { 1. School } \\
\text { 4. Health } \\
\text { 6. Policies }\end{array}$ & $\begin{array}{l}\text { 1. Raising awareness about the } \\
\text { consequences and risks of } \\
\text { sexting } \\
\text { 1. Developing measures } \\
\text { adapted to vulnerable groups } \\
\text { 1. Promoting sexual ethics } \\
\text { 1. Working on the risk factors } \\
\text { associated with the peer } \\
\text { group } \\
\text { 1. Improving the school envi- } \\
\text { ronment } \\
\text { 1. Considering the ideas and } \\
\text { experiences of adolescents } \\
\text { 1. Raising awareness about } \\
\text { gender roles and stereotypes } \\
\text { 1, } 4,6 \text {. Training professionals }\end{array}$ & $\begin{array}{r}\text { Recom- } \\
\text { mends }\end{array}$ \\
\hline 35 & $\begin{array}{l}\text { Powell \& Henry } \\
\quad \text { (2014) }\end{array}$ & Australia & $\begin{array}{l}\text { Sharing/exchanging } \\
\text { sexually explicit } \\
\text { text messages, } \\
\text { pictures or videos } \\
\text { on mobile phones } \\
\text { or social media }\end{array}$ & $\begin{array}{l}\text { Proposes spe- } \\
\text { cific strategies }\end{array}$ & $\begin{array}{l}\text { 1. School } \\
\text { 6. Policies }\end{array}$ & $\begin{array}{l}\text { 1, 6. Considering the ideas and } \\
\text { experiences of adolescents } \\
\text { 1, 6. Promoting sexual ethics } \\
\text { 1, 6. Working on the risk fac- } \\
\text { tors associated with the peer } \\
\text { group } \\
\text { 6. Applying disciplinary or } \\
\text { legal measures }\end{array}$ & No \\
\hline 36 & $\begin{array}{l}\text { Rice et al. } \\
\quad(2014)\end{array}$ & USA & $\begin{array}{l}\text { Sending and receiv- } \\
\text { ing sexually } \\
\text { explicit pictures } \\
\text { or messages on } \\
\text { mobile phones }\end{array}$ & $\begin{array}{l}\text { Proposes spe- } \\
\text { cific strategies }\end{array}$ & $\begin{array}{l}\text { 1. School } \\
\text { 2. Family } \\
\text { 4. Health }\end{array}$ & $\begin{array}{l}\text { 1, } 2,4 \text {. Incorporating informa- } \\
\text { tion about sexting into sex } \\
\text { education programs } \\
\text { 4. Training professionals } \\
\text { 4. Developing specific sexting } \\
\text { programs } \\
\text { 2. Promoting safe and healthy } \\
\text { use of ICT, the Internet and } \\
\text { social networks }\end{array}$ & No \\
\hline 37 & Karaian (2014) & Canada & $\begin{array}{l}\text { Sharing/exchanging } \\
\text { sexual text mes- } \\
\text { sages or pictures } \\
\text { on mobile phones } \\
\text { or by other elec- } \\
\text { tronic means }\end{array}$ & $\begin{array}{l}\text { Proposes spe- } \\
\text { cific strategies }\end{array}$ & $\begin{array}{l}\text { 10. All areas/ } \\
\text { general }\end{array}$ & $\begin{array}{l}\text { 10. Raising awareness about } \\
\text { gender roles and stereotypes }\end{array}$ & No \\
\hline 38 & $\begin{array}{l}\text { Smith et al. } \\
\text { (2014) }\end{array}$ & $\begin{array}{l}\text { United } \\
\text { Kingdom }\end{array}$ & $\begin{array}{l}\text { Sending, receiv- } \\
\text { ing or forwarding } \\
\text { sexually explicit } \\
\text { pictures or mes- } \\
\text { sages by electronic } \\
\text { means, mainly } \\
\text { between mobile } \\
\text { phones }\end{array}$ & $\begin{array}{l}\text { Proposes spe- } \\
\text { cific strategies }\end{array}$ & $\begin{array}{l}\text { 1. School } \\
\text { 2. Family } \\
\text { 6. Policies }\end{array}$ & $\begin{array}{l}\text { 1. Promoting safe and healthy } \\
\text { use of ICT, the Internet and } \\
\text { social networks } \\
1,2,6 \text {. Developing rules and } \\
\text { implementing protocols } \\
\text { 1. Developing measures } \\
\text { adapted to vulnerable groups } \\
\text { 1. Raising awareness about } \\
\text { gender roles and stereotypes }\end{array}$ & $\begin{array}{l}\text { Recom- } \\
\text { mends }\end{array}$ \\
\hline 39 & $\begin{array}{l}\text { Hillman et al. } \\
\text { (2014) }\end{array}$ & Australia & $\begin{array}{l}\text { Sending sexually } \\
\text { explicit pictures, } \\
\text { videos or mes- } \\
\text { sages }\end{array}$ & $\begin{array}{l}\text { Proposes spe- } \\
\text { cific strategies }\end{array}$ & 6. Policies & & No \\
\hline 40 & $\begin{array}{l}\text { Mura et al. } \\
(2014)\end{array}$ & Italy & -- & $\begin{array}{l}\text { Proposes spe- } \\
\text { cific strategies }\end{array}$ & 1. School & $\begin{array}{l}\text { 1. Promoting safe and healthy } \\
\text { use of ICT, the Internet and } \\
\text { social networks } \\
\text { 1. Training professionals }\end{array}$ & No \\
\hline 41 & $\begin{array}{l}\text { Srinivas et al. } \\
\text { (2014) }\end{array}$ & USA & -- & $\begin{array}{l}\text { Proposes spe- } \\
\text { cific strategies }\end{array}$ & $\begin{array}{l}\text { 1. School } \\
\text { 3. Family through } \\
\text { school } \\
\text { 4. Health } \\
\text { 6. Policies }\end{array}$ & $\begin{array}{l}1,4,6 . \text { Training professionals } \\
1,3 . \text { Developing specific sex- } \\
\text { ting programs }\end{array}$ & No \\
\hline
\end{tabular}




\begin{tabular}{|c|c|c|c|c|c|c|c|}
\hline No. & Author(s) & Country & Definition of sexting & $\begin{array}{l}\text { Evidence of } \\
\text { action }\end{array}$ & Areas of action & Lines of action & Evaluation \\
\hline$\overline{42}$ & $\begin{array}{l}\text { Livingstone \& } \\
\text { Smith (2014) }\end{array}$ & $\begin{array}{l}\text { United } \\
\text { Kingdom }\end{array}$ & -- & $\begin{array}{l}\text { Proposes spe- } \\
\text { cific strategies }\end{array}$ & $\begin{array}{l}\text { 10. All areas/ } \\
\text { general }\end{array}$ & & $\begin{array}{r}\text { Recom- } \\
\text { mends }\end{array}$ \\
\hline 43 & $\begin{array}{l}\text { West et al. } \\
\text { (2014) }\end{array}$ & Peru & $\begin{array}{l}\text { Sending and receiv- } \\
\text { ing sexually sug- } \\
\text { gestive or explicit } \\
\text { text messages }\end{array}$ & $\begin{array}{l}\text { Proposes spe- } \\
\text { cific strategies }\end{array}$ & $\begin{array}{l}\text { 1. School } \\
\text { 3. Family through } \\
\text { school } \\
\text { 4. Health } \\
\text { 5. Family through } \\
\text { health }\end{array}$ & $\begin{array}{l}1,3,4,5 \text {. Promoting safe and } \\
\text { healthy use of ICT, the Inter- } \\
\text { net and social networks } \\
1,3,4,5 \text {. Developing specific } \\
\text { sexting programs } \\
\text { 1. Improving the school envi- } \\
\text { ronment }\end{array}$ & No \\
\hline 44 & $\begin{array}{l}\text { Soriano-Ayala } \\
\text { \& González- } \\
\text { Jiménez } \\
(2014)\end{array}$ & Spain & $\begin{array}{l}\text { Sending sexually } \\
\text { suggestive or } \\
\text { explicit pictures, } \\
\text { videos or text mes- } \\
\text { sages on mobile } \\
\text { phones }\end{array}$ & $\begin{array}{l}\text { Proposes spe- } \\
\text { cific strategies }\end{array}$ & 1. School & $\begin{array}{l}\text { 1. Promoting safe and healthy } \\
\text { use of ICT, the Internet and } \\
\text { social networks } \\
\text { 1. Considering the ideas and } \\
\text { experiences of adolescents }\end{array}$ & No \\
\hline 45 & $\begin{array}{l}\text { Schubert \& } \\
\quad \text { Wurf (2014) }\end{array}$ & Australia & $\begin{array}{l}\text { Sending sexually } \\
\text { explicit pictures, } \\
\text { videos or mes- } \\
\text { sages. Although } \\
\text { frequently associ- } \\
\text { ated with mobile } \\
\text { phones, sexting } \\
\text { does not just take } \\
\text { the form of a text } \\
\text { or multimedia } \\
\text { message, but can } \\
\text { also be via email, } \\
\text { publication on } \\
\text { user-generated } \\
\text { sites such as } \\
\text { YouTube or Flickr, } \\
\text { uploaded on social } \\
\text { networks and live } \\
\text { streaming on a } \\
\text { web cam }\end{array}$ & $\begin{array}{l}\text { Proposes spe- } \\
\text { cific strategies }\end{array}$ & 1. School & $\begin{array}{l}\text { 1. Training professionals } \\
\text { 1. Promoting sexual ethics } \\
\text { 1. Incorporating information } \\
\text { about sexting into sex educa- } \\
\text { tion programs } \\
\text { 1. Raising awareness about } \\
\text { gender roles and stereotypes }\end{array}$ & No \\
\hline
\end{tabular}




\begin{tabular}{|c|c|c|c|c|c|c|c|}
\hline No. & Author(s) & Country & Definition of sexting & $\begin{array}{l}\text { Evidence of } \\
\text { action }\end{array}$ & Areas of action & Lines of action & Evaluation \\
\hline$\overline{46}$ & $\begin{array}{l}\text { Van Ouytsel } \\
\text { et al. }(2014 b)\end{array}$ & Belgium & $\begin{array}{l}\text { Sending sexually } \\
\text { suggestive or } \\
\text { explicit pictures, } \\
\text { videos or text } \\
\text { messages by text, } \\
\text { smart phone, } \\
\text { camera phones and } \\
\text { Web } 2.0\end{array}$ & $\begin{array}{l}\text { Proposes spe- } \\
\text { cific strategies }\end{array}$ & $\begin{array}{l}\text { 1. School } \\
\text { 3. Family through } \\
\text { school } \\
\text { 7. Legal advice }\end{array}$ & $\begin{array}{l}\text { 1, 7. Developing rules and } \\
\text { implementing protocols } \\
\text { 1. Encouraging coherence } \\
\text { between the different parties } \\
\text { involved } \\
\text { 1. Incorporating sexting into } \\
\text { preventive programs that } \\
\text { tackle other associated risks } \\
\text { 1. Improving the school envi- } \\
\text { ronment } \\
\text { 1. Training professionals } \\
\text { 1, 3. Developing specific sex- } \\
\text { ting programs } \\
\text { 1. Working on the risk factors } \\
\text { associated with the peer } \\
\text { group } \\
\text { 1, 3. Promoting safe and } \\
\text { healthy use of ICT, the Inter- } \\
\text { net and social networks } \\
\text { 1. Incorporating information } \\
\text { about sexting into sex educa- } \\
\text { tion programs } \\
\text { 1. Promoting sexual ethics } \\
\text { 1. Raising awareness about } \\
\text { gender roles and stereotypes } \\
\text { 1. Considering the ideas and } \\
\text { experiences of adolescents } \\
\text { 1. Applying disciplinary or } \\
\text { legal measures }\end{array}$ & $\begin{array}{l}\text { Recom- } \\
\text { mends }\end{array}$ \\
\hline 47 & $\begin{array}{l}\text { Ybarra \& Mitch- } \\
\text { ell (2014) }\end{array}$ & USA & $\begin{array}{l}\text { Sending sexually } \\
\text { explicit messages } \\
\text { via any means: } \\
\text { in person, on the } \\
\text { Internet, by mobile } \\
\text { phone, text mes- } \\
\text { sage or any other } \\
\text { way }\end{array}$ & $\begin{array}{l}\text { Proposes spe- } \\
\text { cific strategies }\end{array}$ & $\begin{array}{l}\text { 1. School } \\
\text { 2. Family } \\
\text { 4. Health } \\
\text { 8. Law enforce- } \\
\text { ment }\end{array}$ & $\begin{array}{l}\text { 1. Incorporating sexting into } \\
\text { preventive programs that } \\
\text { tackle other associated risks } \\
\text { 1. Incorporating information } \\
\text { about sexting into sex educa- } \\
\text { tion programs } \\
1,2,4,8 \text {. Training profes- } \\
\text { sionals }\end{array}$ & No \\
\hline 48 & Murray (2014) & USA & $\begin{array}{l}\text { Sharing/exchanging } \\
\text { sexually explicit } \\
\text { text messages, } \\
\text { pictures or videos } \\
\text { by mobile phone } \\
\text { or other electronic } \\
\text { devices }\end{array}$ & $\begin{array}{l}\text { Proposes spe- } \\
\text { cific strategies }\end{array}$ & 1. School & $\begin{array}{l}\text { 1. Raising awareness about the } \\
\text { consequences and risks of } \\
\text { sexting } \\
\text { 1. Considering the ideas and } \\
\text { experiences of adolescents } \\
\text { 1. Developing rules and imple- } \\
\text { menting protocols } \\
\text { 1. Developing specific sexting } \\
\text { programs }\end{array}$ & No \\
\hline 49 & $\begin{array}{l}\text { Wood et al. } \\
\text { (2015) }\end{array}$ & $\begin{array}{l}\text { United } \\
\text { Kingdom }\end{array}$ & $\begin{array}{l}\text { Sending and receiv- } \\
\text { ing sexually } \\
\text { explicit pictures or } \\
\text { messages }\end{array}$ & $\begin{array}{l}\text { Proposes spe- } \\
\text { cific strategies }\end{array}$ & 1. School & $\begin{array}{l}\text { 1. Working on the risk factors } \\
\text { associated with the peer } \\
\text { group } \\
\text { 1. Raising awareness about } \\
\text { gender roles and stereotypes } \\
\text { 1. Considering the ideas and } \\
\text { experiences of adolescents } \\
\text { 1. Promoting sexual ethics }\end{array}$ & No \\
\hline
\end{tabular}




\begin{tabular}{|c|c|c|c|c|c|c|c|}
\hline No. & Author(s) & Country & Definition of sexting & $\begin{array}{l}\text { Evidence of } \\
\text { action }\end{array}$ & Areas of action & Lines of action & Evaluation \\
\hline 50 & $\begin{array}{l}\text { Pellai et al. } \\
\text { (2015) }\end{array}$ & Italy & $\begin{array}{l}\text { Sharing/exchanging } \\
\text { sexually explicit } \\
\text { pictures or videos }\end{array}$ & $\begin{array}{l}\text { Proposes spe- } \\
\text { cific strategies }\end{array}$ & $\begin{array}{l}\text { 1. School } \\
\text { 3. Family through } \\
\text { school }\end{array}$ & $\begin{array}{l}\text { 1. Incorporating information } \\
\text { about sexting into sex educa- } \\
\text { tion programs } \\
\text { 1. Training professionals } \\
\text { 1, 3. Developing specific sex- } \\
\text { ting programs } \\
\text { 1. Incorporating sexting into } \\
\text { preventive programs that } \\
\text { tackle other associated risks }\end{array}$ & No \\
\hline 51 & Eugene (2015) & USA & $\begin{array}{l}\text { Sending sexually } \\
\text { suggestive pictures }\end{array}$ & $\begin{array}{l}\text { Proposes spe- } \\
\text { cific strategies }\end{array}$ & 1. School & $\begin{array}{l}\text { 1. Developing specific sexting } \\
\text { programs } \\
\text { 1. Considering the ideas and } \\
\text { experiences of adolescents } \\
\text { 1. Incorporating information } \\
\text { about sexting into sex educa- } \\
\text { tion programs }\end{array}$ & No \\
\hline 52 & $\begin{array}{l}\text { Van Ouytsel } \\
\text { et al. (2015) }\end{array}$ & Belgium & $\begin{array}{l}\text { Sharing/exchanging } \\
\text { sexually explicit } \\
\text { content via mobile } \\
\text { phones and the } \\
\text { Web } 2.0 \text {, such as } \\
\text { social media }\end{array}$ & $\begin{array}{l}\text { Proposes spe- } \\
\text { cific strategies }\end{array}$ & $\begin{array}{l}\text { 1. School } \\
\text { 3. Family through } \\
\text { school } \\
\text { 4. Health } \\
\text { 7. Legal advice }\end{array}$ & $\begin{array}{l}\text { 1. Working on the risk factors } \\
\text { associated with the peer } \\
\text { group } \\
\text { 1. Incorporating sexting into } \\
\text { preventive programs that } \\
\text { tackle other associated risks } \\
\text { 1. Incorporating information } \\
\text { about sexting into sex educa- } \\
\text { tion programs } \\
\text { 1. Promoting safe and healthy } \\
\text { use of ICT, the Internet and } \\
\text { social networks } \\
\text { 1. Training professionals } \\
\text { 1, } 4 \text {. Raising awareness about } \\
\text { the consequences and risks } \\
\text { of sexting } \\
\text { 1, } 7 \text {. Developing rules and } \\
\text { implementing protocols } \\
\text { 1, 3. Developing specific sex- } \\
\text { ting programs } \\
\text { 1. Encouraging coherence } \\
\text { between the different parties } \\
\text { involved }\end{array}$ & $\begin{array}{l}\text { Recom- } \\
\text { mends }\end{array}$ \\
\hline 53 & $\begin{array}{l}\text { Kopecký \& } \\
\text { Szotkowski } \\
(2015)\end{array}$ & $\begin{array}{l}\text { Czech } \\
\text { Republic }\end{array}$ & $\begin{array}{l}\text { Sharing/exchanging } \\
\text { intimate material } \\
\text { via the Internet }\end{array}$ & $\begin{array}{l}\text { Proposes spe- } \\
\text { cific strategies }\end{array}$ & $\begin{array}{l}\text { 1. School } \\
\text { 3. Family through } \\
\text { school }\end{array}$ & $\begin{array}{l}\text { 1. Promoting safe and healthy } \\
\text { use of ICT, the Internet and } \\
\text { social networks } \\
\text { 1. Developing specific sexting } \\
\text { programs } \\
\text { 1, 3. Encouraging coherence } \\
\text { between the different parties } \\
\text { involved }\end{array}$ & No \\
\hline 54 & $\begin{array}{l}\text { Kopecký et al. } \\
\text { (2015) }\end{array}$ & $\begin{array}{l}\text { Czech } \\
\text { Republic }\end{array}$ & $\begin{array}{l}\text { Sharing/exchanging } \\
\text { intimate material } \\
\text { via the Internet }\end{array}$ & $\begin{array}{l}\text { Presents inter- } \\
\text { vention }\end{array}$ & 1. School & $\begin{array}{l}\text { 1. Promoting safe and healthy } \\
\text { use of ICT, the Internet and } \\
\text { social networks } \\
\text { 1. Improving the school envi- } \\
\text { ronment } \\
\text { 1. Developing specific sexting } \\
\text { programs } \\
\text { 1. Incorporating sexting into } \\
\text { preventive programs that } \\
\text { tackle other associated risks }\end{array}$ & No \\
\hline
\end{tabular}




\begin{tabular}{|c|c|c|c|c|c|c|c|}
\hline No. & Author(s) & Country & Definition of sexting & $\begin{array}{l}\text { Evidence of } \\
\text { action }\end{array}$ & Areas of action & Lines of action & Evaluation \\
\hline 55 & Kopecký (2015) & $\begin{array}{l}\text { Slovak } \\
\text { Republic }\end{array}$ & $\begin{array}{l}\text { Sending and receiv- } \\
\text { ing sexually sug- } \\
\text { gestive or explicit } \\
\text { pictures, videos } \\
\text { and text messages }\end{array}$ & $\begin{array}{l}\text { Proposes spe- } \\
\text { cific strategies }\end{array}$ & 1. School & $\begin{array}{l}\text { 1. Raising awareness about the } \\
\text { consequences and risks of } \\
\text { sexting } \\
\text { 1. Developing specific sexting } \\
\text { programs } \\
\text { 1. Training professionals }\end{array}$ & No \\
\hline 56 & $\begin{array}{l}\text { Patrick et al. } \\
\text { (2015) }\end{array}$ & Australia & $\begin{array}{l}\text { Sending and receiv- } \\
\text { ing sexually } \\
\text { explicit pictures, } \\
\text { videos and mes- } \\
\text { sages This also } \\
\text { includes sending } \\
\text { and receiving } \\
\text { sexually sugges- } \\
\text { tive pictures or } \\
\text { videos }\end{array}$ & $\begin{array}{l}\text { Proposes spe- } \\
\text { cific strategies }\end{array}$ & 1. School & $\begin{array}{l}\text { 1. Promoting sexual ethics } \\
\text { 1. Promoting safe and healthy } \\
\text { use of ICT, the Internet and } \\
\text { social networks } \\
\text { 1. Raising awareness about the } \\
\text { consequences and risks of } \\
\text { sexting }\end{array}$ & No \\
\hline 57 & $\begin{array}{c}\text { Choi et al. } \\
\text { (2016) }\end{array}$ & USA & $\begin{array}{l}\text { Sending and receiv- } \\
\text { ing sexually } \\
\text { explicit pictures } \\
\text { via text message, } \\
\text { email or Snapchat }\end{array}$ & $\begin{array}{l}\text { Proposes spe- } \\
\text { cific strategies }\end{array}$ & 1. School & 1. Promoting sexual ethics & No \\
\hline 58 & O'Keeffe (2016) & USA & -- & $\begin{array}{l}\text { Proposes spe- } \\
\text { cific strategies }\end{array}$ & $\begin{array}{l}\text { 4. Health } \\
\text { 5. Family through } \\
\text { health }\end{array}$ & $\begin{array}{l}\text { 4, 5. Promoting safe and } \\
\text { healthy use of ICT, the Inter- } \\
\text { net and social networks }\end{array}$ & No \\
\hline 59 & $\begin{array}{l}\text { Ahern et al. } \\
\text { (2016) }\end{array}$ & USA & -- & $\begin{array}{l}\text { Proposes spe- } \\
\text { cific strategies }\end{array}$ & $\begin{array}{l}\text { 1. School } \\
\text { 3. Family through } \\
\text { school } \\
\text { 4. Health }\end{array}$ & $\begin{array}{l}\text { 1, 3. Developing specific sex- } \\
\text { ting programs } \\
\text { 1, } 3 \text {. Raising awareness about } \\
\text { the consequences and risks } \\
\text { of sexting } \\
\text { 1. Encouraging coherence } \\
\text { between the different parties } \\
\text { involved } \\
\text { 1, } 4 \text {. Training professionals }\end{array}$ & $\begin{array}{l}\text { Recom- } \\
\text { mends }\end{array}$ \\
\hline 60 & $\begin{array}{l}\text { American } \\
\text { College of } \\
\text { Obstetricians } \\
\text { \& Gynecolo- } \\
\text { gists (2016) }\end{array}$ & USA & $\begin{array}{l}\text { Sending sexually } \\
\text { suggestive or } \\
\text { explicit pictures } \\
\text { or messages on } \\
\text { mobile phones }\end{array}$ & $\begin{array}{l}\text { Proposes spe- } \\
\text { cific strategies }\end{array}$ & $\begin{array}{l}\text { 1. School } \\
\text { 2. Family } \\
\text { 4. Health } \\
\text { 5. Family through } \\
\text { health }\end{array}$ & $\begin{array}{l}\text { 4. Raising awareness about the } \\
\text { consequences and risks of } \\
\text { sexting } \\
4,5 . \text { Promoting safe and } \\
\text { healthy use of ICT, the Inter- } \\
\text { net and social networks } \\
1,2,4 \text {. Encouraging coherence } \\
\text { between the different parties } \\
\text { involved }\end{array}$ & No \\
\hline 61 & $\begin{array}{l}\text { Dobson \& } \\
\text { Ringrose } \\
(2016)\end{array}$ & $\begin{array}{l}\text { United } \\
\text { Kingdom } \\
\text { \& Aus- } \\
\text { tralia }\end{array}$ & $\begin{array}{l}\text { Sharing/exchanging } \\
\text { sexually explicit } \\
\text { or suggestive } \\
\text { text messages or } \\
\text { pictures on mobile } \\
\text { phones and social } \\
\text { networks }\end{array}$ & $\begin{array}{l}\text { Proposes spe- } \\
\text { cific strategies }\end{array}$ & $\begin{array}{l}\text { 1. School } \\
\text { 6. Policies }\end{array}$ & $\begin{array}{l}\text { 1. Raising awareness about } \\
\text { gender roles and stereotypes } \\
\text { 1. Promoting safe and healthy } \\
\text { use of ICT, the Internet and } \\
\text { social networks } \\
\text { 1. Promoting sexual ethics } \\
\text { 1, 6. Training professionals }\end{array}$ & No \\
\hline 62 & Lim et al. (2016) & Australia & $\begin{array}{l}\text { Sending and receiv- } \\
\text { ing sexually } \\
\text { explicit pictures } \\
\text { on the Internet or } \\
\text { mobile phones }\end{array}$ & $\begin{array}{l}\text { Proposes spe- } \\
\text { cific strategies }\end{array}$ & 1. School & $\begin{array}{l}\text { 1. Promoting sexual ethics } \\
\text { 1. Working on the risk factors } \\
\text { associated with the peer } \\
\text { group } \\
\text { 1. Raising awareness about the } \\
\text { consequences and risks of } \\
\text { sexting } \\
\text { 1. Incorporating information } \\
\text { about sexting into sex educa- } \\
\text { tion programs }\end{array}$ & $\begin{array}{l}\text { Recom- } \\
\text { mends }\end{array}$ \\
\hline
\end{tabular}




\begin{tabular}{|c|c|c|c|c|c|c|c|}
\hline No. & Author(s) & Country & Definition of sexting & $\begin{array}{l}\text { Evidence of } \\
\text { action }\end{array}$ & Areas of action & Lines of action & Evaluation \\
\hline$\overline{63}$ & $\begin{array}{l}\text { Ferrari et al. } \\
(2016)\end{array}$ & Italy & -- & $\begin{array}{l}\text { Presents inter- } \\
\text { vention }\end{array}$ & $\begin{array}{l}\text { 1. School } \\
\text { 10. All areas/ } \\
\text { general }\end{array}$ & $\begin{array}{l}\text { 1, 10. Improving the school } \\
\text { environment } \\
1,10 . \text { Promoting safe and } \\
\text { healthy use of ICT, the Inter- } \\
\text { net and social networks }\end{array}$ & No \\
\hline 64 & Loveless (2016) & USA & $\begin{array}{l}\text { Sending sexually } \\
\text { suggestive or } \\
\text { explicit pictures } \\
\text { or messages on } \\
\text { mobile phones }\end{array}$ & $\begin{array}{l}\text { Proposes spe- } \\
\text { cific strategies }\end{array}$ & $\begin{array}{l}\text { 1. School } \\
\text { 2. Family } \\
\text { 4. Health } \\
\text { 5. Family through } \\
\text { health }\end{array}$ & $\begin{array}{l}\text { 4. Raising awareness about the } \\
\text { consequences and risks of } \\
\text { sexting } \\
4,5 . \text { Promoting safe and } \\
\text { healthy use of ICT, the Inter- } \\
\text { net and social networks } \\
1,2,4 \text {. Encouraging coherence } \\
\text { between the different parties } \\
\text { involved }\end{array}$ & No \\
\hline 65 & $\begin{array}{l}\text { Davis \& } \\
\text { Schmidt } \\
(2016)\end{array}$ & USA & $\begin{array}{l}\text { Sending, receiving } \\
\text { and forwarding } \\
\text { sexually explicit } \\
\text { pictures and mes- } \\
\text { sages on mobile } \\
\text { phones, the com- } \\
\text { puter or another } \\
\text { digital device }\end{array}$ & $\begin{array}{l}\text { Presents inter- } \\
\text { vention }\end{array}$ & $\begin{array}{l}\text { 1. School } \\
\text { 3. Family through } \\
\text { school } \\
\text { 7. Legal advice }\end{array}$ & $\begin{array}{l}\text { 1. Encouraging coherence } \\
\text { between the different parties } \\
\text { involved } \\
\text { 1, } 7 \text {. Developing rules and } \\
\text { implementing protocols } \\
\text { 1. Developing measures } \\
\text { adapted to vulnerable groups } \\
\text { 1. Promoting safe and healthy } \\
\text { use of ICT, the Internet and } \\
\text { social networks } \\
\text { 1. Training professionals } \\
\text { 1, 3. Developing specific sex- } \\
\text { ting programs } \\
\text { 1. Applying disciplinary or } \\
\text { legal measures }\end{array}$ & $\begin{array}{l}\text { Recom- } \\
\text { mends }\end{array}$ \\
\hline 66 & $\begin{array}{l}\text { Palop et al. } \\
\text { (2016) }\end{array}$ & Spain & $\begin{array}{l}\text { Sending, receiv- } \\
\text { ing or forwarding } \\
\text { sexually explicit } \\
\text { or suggestive } \\
\text { pictures, videos } \\
\text { or messages via } \\
\text { mobile phones, the } \\
\text { Internet or social } \\
\text { networks }\end{array}$ & $\begin{array}{l}\text { Presents inter- } \\
\text { vention }\end{array}$ & 1. School & $\begin{array}{l}\text { 1. Raising awareness about the } \\
\text { consequences and risks of } \\
\text { sexting } \\
\text { 1. Promoting safe and healthy } \\
\text { use of ICT, the Internet and } \\
\text { social networks } \\
\text { 1. Developing specific sexting } \\
\text { programs }\end{array}$ & Yes \\
\hline 67 & Lee et al. (2016) & $\begin{array}{l}\text { South } \\
\text { Korea }\end{array}$ & $\begin{array}{l}\text { Sending sexually } \\
\text { explicit pictures, } \\
\text { videos or messages } \\
\text { via the mobile } \\
\text { phone }\end{array}$ & $\begin{array}{l}\text { Proposes spe- } \\
\text { cific strategies }\end{array}$ & 1. School & $\begin{array}{l}\text { 1. Raising awareness about the } \\
\text { consequences and risks of } \\
\text { sexting } \\
\text { 1. Working on the risk factors } \\
\text { associated with the peer } \\
\text { group }\end{array}$ & No \\
\hline 68 & Ease (2016) & -- & -- & $\begin{array}{l}\text { Proposes spe- } \\
\text { cific strategies }\end{array}$ & 1. School & $\begin{array}{l}\text { 1. Promoting safe and healthy } \\
\text { use of ICT, the Internet and } \\
\text { social networks } \\
\text { 1. Raising awareness about the } \\
\text { consequences and risks of } \\
\text { sexting } \\
\text { 1. Developing rules and imple- } \\
\text { menting protocols }\end{array}$ & No \\
\hline 69 & Speno (2016) & USA & $\begin{array}{l}\text { Sending, receiving } \\
\text { and forwarding } \\
\text { sexually suggestive } \\
\text { or explicit pictures } \\
\text { or text messages } \\
\text { on mobile phones } \\
\text { or other mobile } \\
\text { devices }\end{array}$ & $\begin{array}{l}\text { Proposes spe- } \\
\text { cific strategies }\end{array}$ & 1. School & $\begin{array}{l}\text { 1. Raising awareness about } \\
\text { gender roles and stereotypes } \\
\text { 1. Developing specific sexting } \\
\text { programs }\end{array}$ & No \\
\hline
\end{tabular}




\begin{tabular}{|c|c|c|c|c|c|c|c|}
\hline No. & Author(s) & Country & Definition of sexting & $\begin{array}{l}\text { Evidence of } \\
\text { action }\end{array}$ & Areas of action & Lines of action & Evaluation \\
\hline$\overline{70}$ & $\begin{array}{c}\text { Barrense-Dias } \\
\text { et al. (2017) }\end{array}$ & $\begin{array}{l}\text { Switzer- } \\
\text { land }\end{array}$ & $\overline{--}$ & $\begin{array}{l}\text { Proposes spe- } \\
\text { cific strategies }\end{array}$ & $\begin{array}{l}\text { 10. All areas/ } \\
\text { general }\end{array}$ & $\begin{array}{l}\text { 10. Incorporating sexting into } \\
\text { preventive programs that } \\
\text { tackle other associated risks } \\
\text { 10. Working on the risk factors } \\
\text { associated with the peer } \\
\text { group } \\
\text { 10. Developing specific sexting } \\
\text { programs }\end{array}$ & No \\
\hline 71 & $\begin{array}{l}\text { Anastassiou } \\
\text { (2017) }\end{array}$ & $\begin{array}{l}\text { United } \\
\text { Kingdom }\end{array}$ & $\begin{array}{l}\text { Sending and receiv- } \\
\text { ing sexually } \\
\text { explicit pictures on } \\
\text { the Internet }\end{array}$ & $\begin{array}{l}\text { Recommends } \\
\text { acting, but } \\
\text { does not pro- } \\
\text { vide any spe- } \\
\text { cific strategy }\end{array}$ & $\begin{array}{l}\text { 6. Policies } \\
\text { 10. All areas/ } \\
\text { general }\end{array}$ & & No \\
\hline 72 & $\begin{array}{l}\text { Rodríguez- } \\
\text { Castro et al. } \\
\text { (2017) }\end{array}$ & Spain & $\begin{array}{l}\text { Sending, receiving } \\
\text { and forwarding } \\
\text { sexually sugges- } \\
\text { tive or explicit } \\
\text { pictures, videos or } \\
\text { text messages }\end{array}$ & $\begin{array}{l}\text { Proposes spe- } \\
\text { cific strategies }\end{array}$ & 1. School & $\begin{array}{l}\text { 1. Raising awareness about } \\
\text { gender roles and stereotypes }\end{array}$ & No \\
\hline 73 & $\begin{array}{l}\text { Villacampa } \\
\quad(2017)\end{array}$ & Spain & $\begin{array}{l}\text { Sending, receiving } \\
\text { and forwarding } \\
\text { sexually sugges- } \\
\text { tive or explicit } \\
\text { pictures, videos or } \\
\text { text messages }\end{array}$ & $\begin{array}{l}\text { Proposes spe- } \\
\text { cific strategies }\end{array}$ & $\begin{array}{l}\text { 1. School } \\
\text { 3. Family through } \\
\text { school }\end{array}$ & $\begin{array}{l}\text { 1. Raising awareness about } \\
\text { gender roles and stereotypes } \\
\text { 1. Raising awareness about the } \\
\text { consequences and risks of } \\
\text { sexting } \\
\text { 1. Training professionals } \\
\text { 1, 3. Developing specific sex- } \\
\text { ting programs }\end{array}$ & No \\
\hline 74 & $\begin{array}{l}\text { Wachs et al. } \\
\text { (2017) }\end{array}$ & $\begin{array}{l}\text { Germany, } \\
\text { Nether- } \\
\text { lands \& } \\
\text { Thailand }\end{array}$ & $\begin{array}{l}\text { Sending sexually } \\
\text { suggestive or } \\
\text { explicit pictures } \\
\text { via the Internet }\end{array}$ & $\begin{array}{l}\text { Proposes spe- } \\
\text { cific strategies }\end{array}$ & 1. School & $\begin{array}{l}\text { 1. Raising awareness about the } \\
\text { consequences and risks of } \\
\text { sexting } \\
\text { 1. Promoting safe and healthy } \\
\text { use of ICT, the Internet and } \\
\text { social networks } \\
\text { 1. Developing specific sexting } \\
\text { programs } \\
\text { 1. Promoting sexual ethics }\end{array}$ & No \\
\hline 75 & $\begin{array}{l}\text { Gámez-Guadix } \\
\text { et al. (2017) }\end{array}$ & Spain & $\begin{array}{l}\text { Sending sexually } \\
\text { suggestive or } \\
\text { explicit pictures, } \\
\text { videos or text mes- } \\
\text { sages }\end{array}$ & $\begin{array}{l}\text { Proposes spe- } \\
\text { cific strategies }\end{array}$ & 1. School & $\begin{array}{l}\text { 1. Promoting safe and healthy } \\
\text { use of ICT, the Internet and } \\
\text { social networks } \\
\text { 1. Raising awareness about the } \\
\text { consequences and risks of } \\
\text { sexting } \\
\text { 1. Developing measures } \\
\text { adapted to vulnerable groups }\end{array}$ & No \\
\hline 76 & Krieger (2017) & Canada & $\begin{array}{l}\text { Sending or receiving } \\
\text { self-produced } \\
\text { sexual material } \\
\text { on mobile devices } \\
\text { and social media } \\
\text { sites }\end{array}$ & $\begin{array}{l}\text { Proposes spe- } \\
\text { cific strategies }\end{array}$ & 1. School & $\begin{array}{l}\text { 1. Raising awareness about } \\
\text { gender roles and stereotypes } \\
\text { 1. Developing rules and imple- } \\
\text { menting protocols }\end{array}$ & No \\
\hline 77 & $\begin{array}{l}\text { Strassberg et al. } \\
\text { (2017) }\end{array}$ & USA & $\begin{array}{l}\text { Sending, receiv- } \\
\text { ing or forwarding } \\
\text { sexually explicit } \\
\text { material on mobile } \\
\text { phones }\end{array}$ & $\begin{array}{l}\text { Presents inter- } \\
\text { vention }\end{array}$ & 1. School & $\begin{array}{l}\text { 1. Raising awareness about the } \\
\text { consequences and risks of } \\
\text { sexting }\end{array}$ & Yes \\
\hline
\end{tabular}




\begin{tabular}{|c|c|c|c|c|c|c|c|}
\hline No. & Author(s) & Country & Definition of sexting & $\begin{array}{l}\text { Evidence of } \\
\text { action }\end{array}$ & Areas of action & Lines of action & Evaluation \\
\hline 78 & $\begin{array}{l}\text { Albury et al. } \\
\text { (2017) }\end{array}$ & USA & -- & $\begin{array}{l}\text { Proposes spe- } \\
\text { cific strategies }\end{array}$ & 1. School & $\begin{array}{l}\text { 1. Considering the ideas and } \\
\text { experiences of adolescents } \\
\text { 1. Promoting sexual ethics } \\
\text { 1. Developing specific sexting } \\
\text { programs } \\
\text { 1. Incorporating information } \\
\text { about sexting into sex educa- } \\
\text { tion programs } \\
\text { 1. Promoting safe and healthy } \\
\text { use of ICT, the Internet and } \\
\text { social networks } \\
\text { 1. Raising awareness about } \\
\text { gender roles and stereotypes }\end{array}$ & No \\
\hline 79 & $\begin{array}{l}\text { Delmonico et al. } \\
\text { (2017) }\end{array}$ & USA & -- & $\begin{array}{l}\text { Recommends } \\
\text { acting, but } \\
\text { does not pro- } \\
\text { vide any spe- } \\
\text { cific strategy }\end{array}$ & 1. School & & No \\
\hline 80 & Norman (2017) & Canada & $\begin{array}{l}\text { Sending, receiv- } \\
\text { ing or forwarding } \\
\text { sexually explicit } \\
\text { or suggestive } \\
\text { pictures, videos or } \\
\text { messages }\end{array}$ & $\begin{array}{l}\text { Recommends } \\
\text { acting, but } \\
\text { does not pro- } \\
\text { vide any spe- } \\
\text { cific strategy }\end{array}$ & $\begin{array}{l}\text { 10. All areas/ } \\
\text { general }\end{array}$ & & No \\
\hline 81 & Bhat (2018) & $\begin{array}{l}\text { USA \& } \\
\text { Australia }\end{array}$ & $\begin{array}{l}\text { Sending and receiv- } \\
\text { ing sexually sug- } \\
\text { gestive or explicit } \\
\text { pictures, videos } \\
\text { or messages on } \\
\text { mobile phones } \\
\text { or social network } \\
\text { platforms }\end{array}$ & $\begin{array}{l}\text { Proposes spe- } \\
\text { cific strategies }\end{array}$ & $\begin{array}{l}\text { 1. School } \\
\text { 2. Family }\end{array}$ & $\begin{array}{l}\text { 1. Improving the school envi- } \\
\text { ronment } \\
\text { 1. Training professionals } \\
\text { 1, 2. Encouraging coherence } \\
\text { between the different parties } \\
\text { involved } \\
\text { 1. Developing rules and imple- } \\
\text { menting protocols } \\
\text { 1. Promoting safe and healthy } \\
\text { use of ICT, the Internet and } \\
\text { social networks } \\
\text { 1. Promoting sexual ethics } \\
\text { 1. Developing specific sexting } \\
\text { programs }\end{array}$ & No \\
\hline 82 & $\begin{array}{l}\text { Charteris et al. } \\
\text { (2018) }\end{array}$ & Australia & $\begin{array}{l}\text { Sharing/exchanging } \\
\text { sexually sugges- } \\
\text { tive or explicit } \\
\text { pictures or videos } \\
\text { via mobile phones }\end{array}$ & $\begin{array}{l}\text { Proposes spe- } \\
\text { cific strategies }\end{array}$ & $\begin{array}{l}\text { 1. School } \\
\text { 2. Family }\end{array}$ & $\begin{array}{l}\text { 1, 2. Promoting safe and } \\
\text { healthy use of ICT, the Inter- } \\
\text { net and social networks }\end{array}$ & No \\
\hline 83 & $\begin{array}{l}\text { Frankel et al. } \\
\text { (2018) }\end{array}$ & USA & $\begin{array}{l}\text { Sharing/exchanging } \\
\text { sexually sugges- } \\
\text { tive or explicit } \\
\text { pictures }\end{array}$ & $\begin{array}{l}\text { Proposes spe- } \\
\text { cific strategies }\end{array}$ & $\begin{array}{l}\text { 1. School } \\
\text { 3. Family through } \\
\text { school }\end{array}$ & $\begin{array}{l}\text { 1, 3. Developing specific sex- } \\
\text { ting programs } \\
\text { 1. Incorporating information } \\
\text { about sexting into sex educa- } \\
\text { tion programs } \\
\text { 1. Training professionals } \\
\text { 1. Encouraging coherence } \\
\text { between the different parties } \\
\text { involved } \\
\text { 1. Developing rules and imple- } \\
\text { menting protocols }\end{array}$ & No \\
\hline 84 & $\begin{array}{l}\text { Symons et al. } \\
\text { (2018) }\end{array}$ & Belgium & $\begin{array}{l}\text { Sending sexually } \\
\text { explicit pictures } \\
\text { on the Internet or } \\
\text { mobile phones }\end{array}$ & $\begin{array}{l}\text { Proposes spe- } \\
\text { cific strategies }\end{array}$ & $\begin{array}{l}\text { 1. School } \\
\text { 10. All areas/ } \\
\text { general }\end{array}$ & $\begin{array}{l}\text { 10. Developing specific sexting } \\
\text { programs } \\
\text { 1. Incorporating information } \\
\text { about sexting into sex educa- } \\
\text { tion programs } \\
\text { 1. Raising awareness about } \\
\text { gender roles and stereotypes }\end{array}$ & No \\
\hline
\end{tabular}




\begin{tabular}{|c|c|c|c|c|c|c|c|}
\hline No. & Author(s) & Country & Definition of sexting & $\begin{array}{l}\text { Evidence of } \\
\text { action }\end{array}$ & Areas of action & Lines of action & Evaluation \\
\hline 85 & $\begin{array}{l}\text { Marume et al. } \\
\text { (2018) }\end{array}$ & Zimbabwe & $\begin{array}{l}\text { Sending sexually } \\
\text { explicit pictures }\end{array}$ & $\begin{array}{l}\text { Proposes spe- } \\
\text { cific strategies }\end{array}$ & $\begin{array}{l}\text { 10. All areas/ } \\
\text { general }\end{array}$ & $\begin{array}{l}\text { 10. Incorporating information } \\
\text { about sexting into sex educa- } \\
\text { tion programs } \\
\text { 10. Developing specific sexting } \\
\text { programs }\end{array}$ & \\
\hline 86 & $\begin{array}{l}\text { De Souza \& } \\
\text { Alves (2018) }\end{array}$ & Brazil & $\begin{array}{l}\text { Sharing/exchanging } \\
\text { sexually explicit } \\
\text { texts or messages } \\
\text { by electronic } \\
\text { means }\end{array}$ & $\begin{array}{l}\text { Proposes spe- } \\
\text { cific strategies }\end{array}$ & 1. School & $\begin{array}{l}\text { 1. Incorporating information } \\
\text { about sexting into sex educa- } \\
\text { tion programs } \\
\text { 1. Working on the risk factors } \\
\text { associated with the peer } \\
\text { group } \\
\text { 1. Promoting sexual ethics } \\
\text { 1. Developing specific sexting } \\
\text { programs }\end{array}$ & No \\
\hline 87 & $\begin{array}{l}\text { Wolak et al. } \\
\text { (2018) }\end{array}$ & USA & -- & $\begin{array}{l}\text { Proposes spe- } \\
\text { cific strategies }\end{array}$ & $\begin{array}{l}\text { 1. School } \\
\text { 3. Family through } \\
\text { school }\end{array}$ & $\begin{array}{l}\text { 1. Developing specific sexting } \\
\text { programs } \\
\text { 1. Promoting sexual ethics } \\
\text { 1, 3. Promoting safe and } \\
\text { healthy use of ICT, the Inter- } \\
\text { net and social networks } \\
\text { 1. Raising awareness about } \\
\text { gender roles and stereotypes }\end{array}$ & No \\
\hline 88 & $\begin{array}{l}\text { Stanley et al. } \\
\text { (2018) }\end{array}$ & $\begin{array}{l}\text { United } \\
\text { Kingdom }\end{array}$ & $\begin{array}{l}\text { Sending and receiv- } \\
\text { ing sexually } \\
\text { explicit pictures } \\
\text { or messages on } \\
\text { mobile phones } \\
\text { or social media } \\
\text { platforms }\end{array}$ & $\begin{array}{l}\text { Proposes spe- } \\
\text { cific strategies }\end{array}$ & 1. School & $\begin{array}{l}\text { 1. Working on the risk factors } \\
\text { associated with the peer } \\
\text { group } \\
\text { 1. Raising awareness about } \\
\text { gender roles and stereotypes } \\
\text { 1. Incorporating information } \\
\text { about sexting into sex educa- } \\
\text { tion programs }\end{array}$ & No \\
\hline 89 & $\begin{array}{l}\text { Madigan et al. } \\
\text { (2018) }\end{array}$ & $\begin{array}{l}\text { Canada, } \\
\text { Belgium } \\
\text { \& USA }\end{array}$ & $\begin{array}{l}\text { Sending, receiv- } \\
\text { ing or forwarding } \\
\text { sexually explicit } \\
\text { pictures, videos or } \\
\text { text messages }\end{array}$ & $\begin{array}{l}\text { Proposes spe- } \\
\text { cific strategies }\end{array}$ & $\begin{array}{l}\text { 1. School } \\
\text { 2. Family } \\
\text { 4. Health }\end{array}$ & $\begin{array}{l}\text { 1. Promoting safe and healthy } \\
\text { use of ICT, the Internet and } \\
\text { social networks } \\
\text { 1. Promoting sexual ethics }\end{array}$ & No \\
\hline 90 & $\begin{array}{l}\text { Gregg et al. } \\
\text { (2018) }\end{array}$ & USA & $\begin{array}{l}\text { Sending and receiv- } \\
\text { ing suggestive or } \\
\text { explicit pictures, } \\
\text { messages or } \\
\text { videos }\end{array}$ & $\begin{array}{l}\text { Proposes spe- } \\
\text { cific strategies }\end{array}$ & $\begin{array}{l}\text { 1. School } \\
\text { 2. Family }\end{array}$ & $\begin{array}{l}\text { 1. Improving the school envi- } \\
\text { ronment } \\
\text { 1. Raising awareness about the } \\
\text { consequences and risks of } \\
\text { sexting } \\
\text { 2. Promoting safe and healthy } \\
\text { use of ICT, the Internet and } \\
\text { social networks } \\
\text { 1. Incorporating information } \\
\text { about sexting into sex educa- } \\
\text { tion programs } \\
\text { 1. Working on the risk factors } \\
\text { associated with the peer } \\
\text { group } \\
\text { 1. Developing specific sexting } \\
\text { programs }\end{array}$ & No \\
\hline 91 & $\begin{array}{l}\text { Laguado et al. } \\
\text { (2018) }\end{array}$ & Colombia & $\begin{array}{l}\text { Sending pictures or } \\
\text { videos contain- } \\
\text { ing content that is } \\
\text { sexual to a certain } \\
\text { extent, filmed } \\
\text { or recorded by } \\
\text { the protagonists } \\
\text { thereof, on a } \\
\text { mobile phone }\end{array}$ & $\begin{array}{l}\text { Proposes spe- } \\
\text { cific strategies }\end{array}$ & 1. School & $\begin{array}{l}\text { 1. Incorporating information } \\
\text { about sexting into sex educa- } \\
\text { tion programs } \\
\text { 1. Developing specific sexting } \\
\text { programs }\end{array}$ & No \\
\hline
\end{tabular}




\section{References}

\section{References marked with an asterisk indicate studies included in the systematic review}

*Ahern, N. R., Kemppainen, J., \& Thacker, P. (2016). Awareness and Knowledge of child and adolescent risky behaviors: A parent's perspective. Journal of Child and Adolescent Psychiatric Nursing, 29(1), 6-14. https://doi.org/10.1111/jcap.12129

*Ahern, N. R., \& Mechling, B. (2013). Sexting: Serious problems for youth. Journal of Psychosocial Nursing and Mental Health Services, 51(7), 22-30. https://doi.org/10.3928/02793695-20130 503-02

*Albury, K., \& Crawford, K. (2012). Sexting, consent and young people's ethics: Beyond Megan's story. Continuum, 26(3), 463-473. https://doi.org/10.1080/10304312.2012.665840

*Albury, K., Hasinoff, A. A., \& Senft, T. (2017). From media abstinence to media production: Sexting, young people and education. The Palgrave handbook of sexuality education (pp. 527-545). Palgrave Macmillan. https://doi.org/10.1057/978-1-137-40033-8_26

*American college of obstetricians and gynecologists. (2016). Committee Opinion No. 653: Concerns regarding social media and health issues in adolescents and young adults. Obstetrics and Gynecology, 127(2).

*Anastassiou, A. (2017). Sexting and young people: A review of the qualitative literature. The Qualitative Report, 22(8), 2231-2239.

Atwood, R. M., Beckert, T. E., \& Rhodes, M. R. (2017). Adolescent problematic digital behaviors associated with mobile devices. North American Journal of Psychology, 19(3), 659-684.

*Barrense-Dias, Y., Berchtold, A., Suris, J. C., \& Akre, C. (2017). Sexting and the definition issue. Journal of Adolescent Health, 61(5), 544-554. https://doi.org/10.1016/j.jadohealth.2017.05.009

Baumgartner, S. E., Sumter, S. R., Peter, J., \& Valkenburg, P. M. (2015). Sexual self-presentation on social network sites: Who does it and how is it perceived? Computers in Human Behavior, 50, 91-100. https://doi.org/10.1016/J.CHB.2015.03.061

*Bhat, C. (2018). Proactive cyberbullying and sexting prevention in Australia and the USA. Journal of Psychologists and Counsellors in Schools, 28(1), 120-130. https://doi.org/10.1017/jgc.2017.8

*Boucek, S. G. (2009). Dealing with the Nightmare of "Sexting." The Education Digest, 75(3), 10-12.

*Brown, J. D., Keller, S., \& Stern, S. (2009). Sex, sexuality, sexting, and sexEd: Adolescents and the media. The Prevention Researcher, 16(4), 12-17.

Chalfen, R. (2009). "It's only a picture": sexting, "smutty" snapshots and felony charges. Visual Studies, 24(3), 258-268. https://doi. org/10.1080/14725860903309203

*Charteris, J., Gregory, S., \& Masters, Y. (2018). 'Snapchat', youth subjectivities and sexuality: Disappearing media and the discourse of youth innocence. Gender and Education, 30(2), 205-221. https:// doi.org/10.1080/09540253.2016.1188198

*Choi, H. J., Van Ouytsel, J., \& Temple, J. R. (2016). Association between sexting and sexual coercion among female adolescents. Journal of Adolescence, 53, 164-168. https://doi.org/10.1016/j. adolescence.2016.10.005

Cooper, K., Quayle, E., Jonsson, L., \& Svedin, C. G. (2016). Adolescents and self-taken sexual images: A review of the literature. Computers in Human Behavior, 55, 706-716. https://doi.org/10. 1016/j.chb.2015.10.003

*Dake, J. A., Price, J. H., Maziarz, L., \& Ward, B. (2012). Prevalence and correlates of sexting behavior in adolescents. American Journal of Sexuality Education, 7(1), 1-15. https://doi.org/10.1080/ 15546128.2012.650959
*Davis, N., \& Schmidt, C. (2016). Cyberbullying and cyber abuse intervention: The three-tiered model for schools. Journal of Creativity in Mental Health, 11(3-4), 366-377. https://doi.org/10.1080/ 15401383.2016.1238792

*Delmonico, D. L., Putney, H. L., \& Griffin, E. J. (2017). Sexting and the @ generation: Implications, motivations, and solutions. In K. S. Young \& C. N. de Abreu (Eds.), Internet addiction in children and adolescents: Risk factors, assessment, and treatment (p. 305). Springer Publishing Company.

* De Souza, F. \& Alves, R. (2018). A prática cultural do sexting entre adolescentes: Notas para a delimitação do objeto de estudo. Acta Comportamentalia: Revista Latina de Análisis Del Comportamiento, 26(1).

*Dessoff, A. (2011). Tough new issues refocus health education. District Administration, 47(1), 71-74.

*Diliberto, G., \& Mattey, E. (2009). Sexting: Just how much of a danger is it and what can school nurses do about it? NASN School Nurse, 24(6), 262-267. https://doi.org/10.1177/1942602X09348652

*Dobson, A. S., \& Ringrose, J. (2016). Sext education: Pedagogies of sex, gender and shame in the schoolyards of Tagged and Exposed. Sex Education, 16(1), 8-21. https://doi.org/10.1080/14681811. 2015.1050486

*Döring, N. (2014). Consensual sexting among adolescents: Risk prevention through abstinence education or safer sexting? Cyberpsychology: Journal of Psychosocial Research on Cyberspace. https://doi.org/10.5817/cp2014-1-9

*Ease, L. (2016). Added danger of sexting. TES: times Educational Supplement, 5184, 43-43.

Englander, E., \& McCoy, M. (2017). Pressured sexting and revenge porn in a sample of Massachusetts adolescents. International Journal of Technoethics (IJT), 8(2), 16-25. https://doi.org/10. 4018/ijt.2017070102

*Eugene, J. (2015). It's more than just "Sext" - a brief discussion on sexting activity among teens. Journal of Adolescent Health, 57(1), 128-129. https://doi.org/10.1016/j.jadohealth.2015.02.021

*Fenaughty, J., \& Harré, N. (2013). Factors associated with distressing electronic harassment and cyberbullying. Computers in Human Behavior, 29(3), 803-811. https://doi.org/10.1016/j.chb.2012. 11.008

*Ferrari, S., Nardi, E., Rivoltella, P., \& Veronelli, A. (2016). Social $\&$ theatre. Body and identity education in sexting prevention. Comunicazioni Sociali, 2(2), 261-271. https://doi.org/10.1089/ cyber.2012.0288

Fox, J., \& Warber, K. M. (2013). Romantic relationship development in the age of Facebook: An exploratory study of emerging adults' perceptions, motives, and behaviors. Cyberpsychology, Behavior, and Social Networking, 16(1), 3-7.

*Frankel, A. S., Bass, S. B., Patterson, F., Dai, T., \& Brown, D. (2018). Sexting, risk behavior, and mental health in adolescents: An examination of 2015 Pennsylvania youth risk behavior survey data. Journal of School Health, 88(3), 190-199. https://doi.org/ 10.1111/josh.12596

*Gámez-Guadix, M., de Santisteban, P., \& Resett, S. (2017). Sexting among Spanish adolescents: Prevalence and personality profiles. Psicothema, 29(1), 29-34. https://doi.org/10.7334/psicothema 2016.222

García-Moya, I., Bunn, F., Jiménez-Iglesias, A., Paniagua, C., \& Brooks, F. M. (2018). The conceptualisation of school and teacher connectedness in adolescent research: A scoping review of literature. Educational Review. https://doi.org/10.1080/00131911. 2018.1424117

Garmendia, M., Jiménez, E., Casado, M. A., \& Mascheroni, G. (2016). Net children go mobile: Riesgos y oportunidades en internet y el uso de dispositivos móviles entre menores españoles (2010 2015). https://bit.ly/2viYYc2 
Gewirtz-Meydan, A., Mitchell, K. J., \& Rothman, E. F. (2018). What do kids think about sexting? Computers in Human Behavior, 86, 256-265. https://doi.org/10.1016/j.chb.2018.04.007

Gómez, L. C., \& Ayala, E. S. (2014). Psychological aspects, attitudes and behaviour related to the practice of sexting: A systematic review of the existent literature. Procedia-Social and Behavioral Sciences, 132, 114-120. https://doi.org/10.1016/j.sbspro.2014. 04.286

*Gregg, D., Somers, C. L., Pernice, F. M., Hillman, S. B., \& Kernsmith, P. (2018). Sexting rates and predictors from an urban midwest high school. Journal of School Health, 88(6), 423-433. https:// doi.org/10.1111/josh.12628

*Hillman, H., Hooper, C., \& Choo, K. K. R. (2014). Online child exploitation: Challenges and future research directions. Computer Law \& Security Review, 30(6), 687-698. https://doi.org/10.1016/j.clsr. 2014.09.007

*Hinduja, S., \& Patchin, J. W. (2012). School climate 2.0: Preventing cyberbullying and sexting one classroom at a time. Corwin Press.

*Houck, C. D., Barker, D., Rizzo, C., Hancock, E., Norton, A., \& Brown, L. K. (2014). Sexting and sexual behavior in at-risk adolescents. Pediatrics. https://doi.org/10.1542/peds.2013-1157d

*Karaian, L. (2014). Policing 'sexting': Responsibilization, respectability and sexual subjectivity in child protection/crime prevention responses to teenagers' digital sexual expression. Theoretical Criminology, 18(3), 282-299. https://doi.org/10.1177/13624 80613504331

*Kenny, M. C. (2014). Sex education: attitude of adolescents, cultural differences and schools' challenges. Nova Science Publishers.

Klettke, B., Hallford, D., \& Mellor, D. J. (2014). Sexting prevalence and correlates: A systematic literature review. Clinical Psychology Review, 34(1), 44-53. https://doi.org/10.1016/j.cpr.2013.10.007

*Kopecký, K. (2012). Sexting among Czech preadolescents and adolescents. The New Educational Review, 28(2), 39-48.

*Kopecký, K. (2015). Sexting among Slovak pubescents and adolescent children. Procedia-Social and Behavioral Sciences, 203, 244-250. https://doi.org/10.1016/j.sbspro.2015.08.289

*Kopecký, K., \& Szotkowski, R. (2015). Cyberbullying and other forms of risky behaviour on the internet by Czech children. Adiktologie, 15(3), 226-233.

*Kopecký, K., Szotkowski, R., \& Hejsek, L. (2015). Project Webrangers-The example of cooperation of academic and commercial sector. INTED Proceedings, 6366-6367.

*Krieger, M. A. (2017). Unpacking "Sexting": A systematic review of nonconsensual sexting in legal, educational, and psychological literatures. Trauma, Violence, \& Abuse, 18(5), 593-601. https:// doi.org/10.1177/1524838016659486

*Laguado, J., Gallardo, H., \& Vergel, M. (2018). Fundamentos epistemológicos para un modelo psico-pedagógico en educación sexual. Revista Logos Ciencia \& Tecnología, 10(1), 95-117. https://doi. org/10.22335/rlct.v10i1.510

*Lee, C. H., Moak, S., \& Walker, J. T. (2016). Effects of self-control, social control, and social learning on sexting behavior among south Korean youths. Youth \& Society, 48(2), 242-264. https:// doi.org/10.1177/0044118X13490762

*Lim, M., Vella, A., Horyniak, D., \& Hellard, M. (2016). Exploring attitudes towards sexting of young people: A cross-sectional study. Sexual Health, 13(6), 530-535. https://doi.org/10.1071/sh16029

Ling, R. (2004). The mobile connection: The cell phone's impact on society. Morgan Kaufmann.

Livingstone, S., \& Smith, P. (2014). Annual research review: Harms experienced by child users of online and mobile technologies: The nature, prevalence and management of sexual and aggressive risks in the digital age. Journal of Child Psychology and Psychiatry, 55(6), 635-654. https://doi.org/10.1111/jcpp.12197

*Livingstone, S., \& Görzig, A. (2014). When adolescents receive sexual messages on the internet: Explaining experiences of risk and harm. Computers in Human Behavior, 33, 8-15. https://doi.org/ 10.1016/j.chb.2013.12.021

*Loveless, M. (2016). Concerns regarding social media and health issues in adolescents and young adults. Obstetrics and Gynecology, 127(2), e62-e65. https://doi.org/10.1097/AOG.0000000000 001313

*Madigan, S., Ly, A., Rash, C. L., Van Ouytsel, J., \& Temple, J. R. (2018). Prevalence of multiple forms of sexting behavior among youth. JAMA Pediatrics, 172(4), 327-335. https://doi.org/10. 1001/jamapediatrics.2017.5314

*Manzo, K. K. (2009). Administrators confront student. Education Digest: Essential Readings Condensed for Quick Review, 75(3), $13-16$.

*Martín, J. M., Díaz, R., \& Valiente-Barroso, C. (2013). Use of social media in secondary education students and impact of a risk prevention programme associated to the internet. INTED2013 Proceedings, 82-86.

*Marume, A., Maradzika, J., \& January, J. (2018). Adolescent sexting and risky sexual behaviours in Zimbabwe: A cross-sectional study. Sexuality \& Culture, 22(3), 931-941. https://doi.org/10. 1007/s12119-018-9508-4

*McEachern, A. G., McEachern-Ciattoni, R. T., \& Martin, F. (2012). Sexting: New challenges for schools and professional school counselors. Journal of School Counseling, 10(20), 1-28.

Medrano, J. L. J., Lopez Rosales, F., \& Gámez-Guadix, M. (2018). Assessing the links of sexting, cybervictimization, depression, and suicidal ideation among university students. Archives of Suicide Research, 22(1), 153-164. https://doi.org/10.1080/13811 118.2017.1304304

*Mitchell, K. J., Finkelhor, D., Jones, L. M., \& Wolak, J. (2012). Prevalence and characteristics of youth sexting: A national study. Pediatrics, 129(1), 13-20. https://doi.org/10.1542/peds.2011-1730

Montiel, I., Carbonell, E., \& Pereda, N. (2016). Multiple online victimization of Spanish adolescents: Results from a community sample. Child Abuse \& Neglect, 52, 123-134. https://doi.org/10.1016/J CHIABU.2015.12.005

Mori, C., Temple, J. R., Browne, D., \& Madigan, S. (2019). Association of sexting with sexual behaviors and mental health among adolescents. JAMA Pediatrics. https://doi.org/10.1001/jamapediat rics.2019.1658

*Mura, G., Bernardi, M., \& Diamantini, D. (2014). Diffusion of ICT related problems among students: The teachers' experience. Revista De Pedagogía, 66(3), 105-120. https://doi.org/10.13042/ bordon.2014.66307

*Murray, D. (2014). A Survey of the practices and perceptions of students in one catholic high school on the use of the internet in relation to safety, cyberbullying, and sexting. University of San Francisco.

*Norman, J. (2017). Implications of parenting behaviour and adolescent attachment for understanding adolescent sexting. University of windsor

O'Bannon, B. W., \& Thomas, K. (2014). Teacher perceptions of using mobile phones in the classroom: Age matters! Computers \& Education, 74, 15-25. https://doi.org/10.1016/j.compedu.2014. 01.006

*O'Keeffe, G. (2016). Social media: Challenges and concerns for families. Pediatric Clinics, 63(5), 841-849.

Olivari, M., \& Confalonieri, E. (2017). Adolescenti e sexting: Una review della letteratura. Maltrattamento e Abuso All'infanzia, 2, 119-214. https://doi.org/10.3280/mal2017-002007

*Palop, M., Chalmeta, R., \& Mollar, M. (2016). Curriculum design of a sextorsion prevention course. ICERI2016 Proceedings, 57285731. https://doi.org/10.21125/iceri.2016.0286

*Patrick, K., Heywood, W., Pitts, M., \& Mitchell, A. (2015). Demographic and behavioural correlates of six sexting behaviours 
among Australian secondary school students. Sexual Health, 12(6), 480-487. https://doi.org/10.1071/sh15004

*Pellai, A., Erba, S., Ciampelli, A., Iemmi, D., Bronzin, S., Capobussi, M., Degnoni, V., Gattoni, M. E., \& Corradin, M. (2015). Epidemiology of sexting. Minerva Pediatrica, 67(1), 1-9.

*Powell, A., \& Henry, N. (2014). Blurred lines? Responding to 'sexting' and gender-based violence among young people. Children Australia, 39(2), 119-124. https://doi.org/10.1017/cha.2014.9

*Rice, E., Gibbs, J., Winetrobe, H., Rhoades, H., Plant, A., Montoya, J., \& Kordic, T. (2014). Sexting and sexual behavior among middle school students. Pediatrics. https://doi.org/10.1542/peds. 2013-2991d

*Rice, E., Rhoades, H., Winetrobe, H., Sanchez, M., Montoya, J., Plant, A., \& Kordic, T. (2012). Sexually explicit cell phone messaging associated with sexual risk among adolescents. Pediatrics, 130(4), 667-673. https://doi.org/10.1542/peds.2012-0021

Ringrose, J., Gill, R., Livingstone, S., \& Harvey, L. (2012). A qualitative study of children, young people and 'sexting': A report prepared for the NSPCC. https://bit.ly/2Wc7QLK

*Rodríguez-Castro, Y., Alonso-Ruido, P., González-Fernández, A., Lameiras-Fernández, M., \& Carrera-Fernández, M. V. (2017). Spanish adolescents' attitudes towards sexting: Validation of a scale. Computers in Human Behavior, 73, 375-384. https://doi. org/10.1016/j.chb.2017.03.049

*Russo, C., \& Arndt, K. (2010). Technology and the Law: The dangers of sexting in schools. School Business Affairs, 76(4), 36-38.

*Sadhu, J. M. (2012). Sexting: The impact of a cultural phenomenon on psychiatric practice. Academic Psychiatry, 36(1), 76-81. https:// doi.org/10.1176/appi.ap.10100146

*Schubert, A. (2014). Adolescent sexting in schools: Criminalisation, policy imperatives, and duty of care. Issues in Educational Research, 24(2), 190-211.

*Segool, N. K., \& Crespi, T. D. (2011). Sexting in the Schoolyard. Communiqué, 39(8), 1-30.

*Siegle, D. (2010). Cyberbullying and sexting: Technology abuses of the 21st century. Gifted Child Today, 33(2), 14-65. https://doi. org/10.1177/107621751003300206

*Skarbek, D., \& Mooney, M. E. (2011). Can txting B bad 4 Spec. Ed Stdnts? Sexting and its implications for children with disabilities. In Sexual Abuse: Types, Signs and Treatments (pp. 129-141). Nova Science Publishers.

Smith, L. W., Liu, B., Degenhardt, L., Richters, J., Patton, G., Wand, H., Cross, D., Hocking, J. S., Skinner, S. R., Cooper, S., Lumby, C., Kaldor, J. M., \& Guy, R. (2016). Is sexual content in new media linked to sexual risk behaviour in young people? A systematic review and meta-analysis. Sexual Health, 13(6), 501-515. https:// doi.org/10.1071/sh16037

*Smith, P. K., Thompson, F., \& Davidson, J. (2014). Cyber safety for adolescent girls: Bullying, harassment, sexting, pornography, and solicitation. Current Opinion in Obstetrics and Gynecology, 26(5), 360-365. https://doi.org/10.1097/gco.0000000000000106

*Soriano-Ayala, E., \& González-Jiménez, A. J. (2014). Spanish and Moroccan youths on social networks: A quantitative study in Spain. Procedia-Social and Behavioral Sciences. https://doi.org/ 10.1016/j.sbspro.2014.04.274

*Speno, A. (2016). Adolescent sexting: An examination of the psychosocial contributions to the creation and sharing of sexual images. University of Missouri.

*Srinivas, A., White, M., \& Omar, H. (2014). Teens Texting. In J. Merrick, A. Tenenbaum, \& H. A. Omar (Eds.), School, Adolescence, and Health Issues (pp. 67-72).

*Stanley, N., Barter, C., Wood, M., Aghtaie, N., Larkins, C., Lanau, A., \& Överlien, C. (2018). Pornography, sexual coercion and abuse and sexting in young people's intimate relationships: A European study. Journal of Interpersonal Violence, 33(19), 2919-2944. https://doi.org/10.1177/0886260516633204
*Strasburger, V. C., Jordan, A. B., \& Donnerstein, E. (2012). Children, adolescents, and the media: Health effects. Pediatric Clinics, 59(3), 533-587.

*Strassberg, D. S., Cann, D., \& Velarde, V. (2017). Sexting by high school students. Archives of Sexual Behavior, 46(6), 1667-1672. https://doi.org/10.1007/s10508-016-0926-9

*Strassberg, D. S., McKinnon, R. K., Sustaíta, M. A., \& Rullo, J. (2013). Sexting by high school students: An exploratory and descriptive study. Archives of Sexual Behavior, 42(1), 15-21. https://doi.org/ 10.1007/s10508-012-9969-8

Sweeny, J., \& Slack, J. (2017). Sexting as 'Sexual Behavior' under rape shield laws. International Journal of Cyber Criminology, 246

*Symons, K., Ponnet, K., Walrave, M., \& Heirman, W. (2018). Sexting scripts in adolescent relationships: Is sexting becoming the norm? New Media \& Society, 20(10), 3836-3857. https://doi.org/ $10.1177 / 1461444818761869$

*Taylor, K. R. (2009). “Sexting”: Fun or Felony? Principal Leadership, 9(8), 60-62.

*Temple, J. R., Paul, J. A., van den Berg, P., Le, V. D., McElhany, A., \& Temple, B. W. (2012). Teen sexting and its association with sexual behaviors. Archives of Pediatrics \& Adolescent Medicine, 166(9), 828-833. https://doi.org/10.1001/archpediatrics.2012.835

*Temple, J. R., Strasburger, V. C., Zimmerman, H., \& Madigan, S. (2019). Sexting in youth: Cause for concern? The Lancet Child \& Adolescent Health, 3(8), 520-521. https://doi.org/10.1016/ S2352-4642(19)30199-3

*Theodore, S. (2011). Integrated response to sexting: Utilization of parents and schools in deterrence. Journal of Contemporary Health Law and Policy, 27, 365.

*Uhler, S. F., \& Smith, G. T. (2012). Regulating conduct in new frontiers. Education Digest: Essential Readings Condensed for Quick Review, 77(8), 47-52.

Urrútia, G., \& Bonfill, X. (2010). PRISMA declaration: A proposal to improve the publication of systematic reviews and meta-analyses. Medicina Clinica, 135(11), 507-511. https://doi.org/10.1016/j. medcli.2010.01.015

*Van Ouytsel, J., Van Gool, E., Ponnet, K., \& Walrave, M. (2014a). Brief report: The association between adolescents' characteristics and engagement in sexting. Journal of Adolescence, 37(8), 1387-1391. https://doi.org/10.1016/j.adolescence.2014.10.004

Van Ouytsel, J., Van Gool, E., Walrave, M., Ponnet, K., \& Peeters, E. (2016). Exploring the role of social networking sites within adolescent romantic relationships and dating experiences. Computers in Human Behavior, 55, 76-86. https://doi.org/10.1016/j. chb.2015.08.042

Van Ouytsel, J., Walrave, M., Ponnet, K., \& Heirman, W. (2015). The association between adolescent sexting, psychosocial difficulties, and risk behavior. The Journal of School Nursing, 31(1), 54-69. https://doi.org/10.1177/1059840514541964

*Van Ouytsel, J., Walrave, M., \& Van Gool, E. (2014b). Sexting: between thrill and fear-how schools can respond. The Clearing House: A Journal of Educational Strategies, Issues and Ideas, 87(5), 204-212. https://doi.org/10.1080/00098655.2014.918532

*Van Ouytsel, J., Walrave, M., \& Ponnet, K. (2018). Adolescent sexting research: The challenges ahead. JAMA Pediatrics, 172(5), 405. https://doi.org/10.1001/jamapediatrics.2018.0013

*Villacampa, C. (2017). Teen sexting: Prevalence, characteristics and legal treatment. International Journal of Law, Crime and Justice, 49, 10-21. https://doi.org/10.1016/j.ijlcj.2017.01.002

*Wachs, S., Wright, M. F., \& Wolf, K. D. (2017). Psychological correlates of teen sexting in three countries-direct and indirect associations between self-control, self-esteem, and sexting. International Journal of Developmental Science, 11(3-4), 109-120. https://doi. org/10.3233/dev-160212

*Walker, S., Sanci, L., \& Temple-Smith, M. (2011). Sexting and young people: Experts' views. Youth Studies Australia, 30(4), 8-16. 
*West, J. H., Lister, C. E., Hall, P. C., Crookston, B. T., Snow, P. R., Zvietcovich, M. E., \& West, R. P. (2014). Sexting among Peruvian adolescents. BMC Public Health, 14(1), 811. https://doi.org/10. 1186/1471-2458-14-811

*Wolak, J., Finkelhor, D., \& Mitchell, K. J. (2012). How often are teens arrested for sexting? Data from a national sample of police cases. Pediatrics, 129(1), 4-12. https://doi.org/10.1542/peds.2011-2242

*Wolak, J., Finkelhor, D., Walsh, W., \& Treitman, L. (2018). Sextortion of minors: Characteristics and dynamics. Journal of Adolescent Health, 62(1), 72-79. https://doi.org/10.1016/j.jadohealth.2017. 08.014

*Wood, M., Barter, C., Stanley, N., Aghtaie, N., \& Larkins, C. (2015). Images across Europe: The sending and receiving of sexual images and associations with interpersonal violence in young people's relationships. Children and Youth Services Review, 59, 149-160. https://doi.org/10.1016/j.childyouth.2015.11.005
Woodward, V. H., Evans, M., \& Brooks, M. (2017). Social and psychological factors of rural youth sexting: An examination of genderspecific models. Deviant Behavior, 38(4), 461-476. https://doi. org/10.1080/01639625.2016.1197020

*Wurtele, S., \& Miller-Perrin, C. (2014). Preventing technology-initiated sexual victimization of youth: A developmental perspective. In M. C. Kenny (Ed.), Sex Education: Attitude of Adolescents, Cultural Differences and Schools' Challenges (pp. 147-175). Nova.

*Ybarra, M. L., \& Mitchell, K. J. (2014). "Sexting" and its relation to sexual activity and sexual risk behavior in a national survey of adolescents. Journal of Adolescent Health, 55(6), 757-764. https://doi.org/10.1016/j.jadohealth.2014.07.012

Publisher's Note Springer Nature remains neutral with regard to jurisdictional claims in published maps and institutional affiliations. 